\title{
HANEFî MEZHEBİNDE SAHÂBE KAVLİNİN HÜCCET DEĞERİ
}

\section{Recep ÇETINTAŞ*}

\section{Özet:}

Erken döneme ait muhtelif furû' kaynaklarında sahâbî kavli konusunda Ebû Hanîfe'ye (ö. 150/767) isnat edilen bazı rivayetler mevcut olmakla birlikte Serahsî (ö. 483/1090) hariç ilk dönem Hanefî usulcüler eserlerinde bunlara yer vermemiştir. Yalnızca Serahsî mezkûr rivayetlerden bir tanesini el-Usûl adlı eserinde rivayet etmiştir. Diğerlerinin bu konuda Ebü’l-Hasen el-Kerhî'nin (ö. 340/952) etkisinde kaldıkları anlaşılmaktadır. Zira Kerhî, sahâbe icmâ'ı dışında Ebû Hanîfe'den bu konuda sağlam yollarla bir sözün gelmediğini söylemiştir. Bu sebeple ilk dönem Hanefî usûlcüler bu rivayetlerden daha ziyade tümevarım yöntemiyle Ebû Hanîfe'nin fıkhî çözümlemelerini inceleyerek bu konudaki görüşünü tespit etme yöntemini tercih etmişlerdir. Neticede onun sahâbe icmâ'ı yanında akıl ile kavranamayacak konularda muhalifi bilinmeyen sahâbe kavliyle amel etme konusunda tatbikatının birleştiği; akıl ile kavranabilecek konulardaki sahâbî kavliyle amel etme hususunda ise tatbikatının farklı olduğu sonucuna varmışlardır. Bundan dolayı mütekaddimûn ve müteahhirûn Hanefî usûlcüler sahâbe icmâ'ı yanında akıl ile kavranamayacak meselelerde muhâlifi bilinmeyen sahâbî kavlinin tâbiûn ve onlardan sonra gelen müçtehitler için hüccet teşkil edeceği konusunda görüş birliği etmişlerdir. Buna mukabil akıl ve re'y ile kavranabilecek konularda sahâbe kavlinin hüccet teşkil edip etmeyeceği konusunda görüş ayrılığına düşmüşlerdir. Bu konuda Ebû Saîd el-Berdaî (ö. 317/930) ile talebesi Ebü'l-Hasen el-Kerhî’nin temsil ettiği iki görüş ortaya çıkmıştır.

Ebû Saîd el-Berdaî akılla kavranamayacak konularda olduğu gibi akılla kavranabilecek konularda da sahâbe kavliyle amel etmenin vacip olduğu görüşünü benimsemiştir. Berdaî̀den sonra gelen Hanefî usûlcülerin çoğunluğu da bu görüşü benimsemişlerdir.

Ebü'l-Hasen el-Kerhî ise hocası Berdaî'nin aksine akıl ve re'y ile kavranabilecek konulardaki sahâbî kavliyle amel etmenin câiz olmadığı görüşünü benimsemiştir. Ancak Debûsî (ö. 430/1039) ve İbnü'l-Hümam (ö. 861/1457) dışında Kerhî̀nin bu görüşüne meyleden usûlcüye neredeyse rastlanmamaktadır.

Anahtar Kelimeler: Hanefî Mezhebi, Sahâbî Kavli, Sahâbe İcmâ‘ı, Fetva, Hüccet Değeri.

\section{The Legal Value Of The Saying Of The Companions In The Sect Of Hanafite}

\begin{abstract}
:
Although there are some narrations attributed to Abū Hanīfa (d. 150/767) in the various sources of early period, the majority of the Hanafite scholars in the early period except Sarahsī (d. 483/1090) did not include them in their works. Only Sarahsī mentioned one of these narrations in his work al-Usūl. It is understood that the other scholars were clearly under the influence of Abū al-Hasan al-Karhī (d. 340/952) in this matter. Because Karhī said that Abû Hanīfa, apart from the consensus (ijma) of the companion of the Prophet, did not say any thing in this regard. For this reason, the Hanafite scholars of the early period preferred the method of determining his views on this subject by examining the fiqh solutions of Abū Hanīfa by means of induction method rather than
\end{abstract}

\footnotetext{
Yrd. Doç. Dr., Bülent Ecevit Üniversitesi, İlahiyat Fakültesi. recepcetintas2006@yahoo.com.tr
} 
these narrations. In the end, they have came to the conclusion that the practices of Abû Hanīfa are united in dealing with the consensus of companions and the saying of the companion that no one of them opposes him on the subjects can not be comprehended by the means of aql and that his exercises were different in dealing with the saying of the companion on the subjects that can be comprehended by aql. Hence, the Hanafite scholars allied that consensus of the companions and the saying of the companion on the subjects that would not be comprehended by aql would constitute a legal evidence for the mujtahids who followed them. But they have disagreed on whether the saying of the companions on subjects that can be comprehended by aql would constitute a legal evidence for the mujtahids who followed them or not. In this respect, two different views emerged, represented by Abū Saed al-Berdaī (d. 317/930) and his student Abū al-Hasan al-Karhī.

Abū Saed al-Berdaī adopted imitating to the saying of the Companion as absolute obligation (wajib) whether it is in matters that can be comprehended by aql (mind) or that can not be comprehended by aql. The great majority of the Hanafite scholars after Berdai adopted the same opinion. But Abū al-Hasan al-Karhī while accepting the opinion of his teacher Berdai about the saying of the companion in matters that can not be comprehended by aql he had rejected the permissssiblity to act according to the saying of the companion in matters may be known by aql. But there are almost no scholars declined Karhī's opinion about the saying of the companion in matters may be comprehended by aql except Dabūsī (d. 430/1039) and Ibn al-Khumam (d. 861/1457).

Keywords: Sect of Hanafite, Saying of the Companions, Consensus of Companions, Fatwa, Legal Value.

\section{Giriş}

Muhaddislere göre sahâbî, mü'min olarak Hz. Peygamber'i gören ve bu hal üzere ölen kimseye denir. ${ }^{1} \mathrm{~Hz}$. Peygamber ile gerek uzun süre gerekse kısa bir süre beraber olan, ondan hadis rivayet eden veya etmeyen, onunla birlikte gazaya katılan veya katılmayan, onunla oturup kalkmasa da onu bir kere gören ve körlük gibi bir arızadan dolayı göremeyen herkes bu tanımın kapsamına dâhil olur. ${ }^{2}$ Şüphesiz bu tanımın kapsamına taklid edilmesi icmâ ile caiz olmayan bedevî ve fâsık olan sahâbîler de girer. Dolayısıyla usulcülerin, sözlerinin hüccet değerini tartıştıkları sahâbe, muhaddislerin tanımına giren sahâbîlerin tamamı değildir.

Şihâbüddin Ebi'l-Fazl Ahmed b. Ali b. Muhammed b. Hacer el-Askalânî, el-İsâbe fí temyîzi'ssahâbe, Beyrut: Dâru'l-kütübi'l-ilmiyye, ts. c. 1, s. 4; İ̉n Hazm, sahâbîyi; “Hz. Peygamberle bir saat bile olsa oturup kalkmıs, ondan bir kelime veya daha fazla olsun hadis işitmiş yahut ezberleyeceği bir meseleye şahit olmuş ve bu hal üzere ölünceye kadar (bize) nifakı ulaşmamış ve münafıklığı meşhur olmamış herkes sahâbîdir." şeklinde tarif etmiştir. bk., Ebû Muhammed Ali b. Ahmed b. Saîd b. Hazm, el-ïhkâm fì usûli'l-ahkûm (tahk.: Mahmud Hâmid Osman), Kâhire, Dâru'l-hadîs, 2005, 5, s. 701. İbn Hacer, İsâbe, c. 1, s. 4. 
Usûlcülerin çoğunluğuna göre sahâbî, sınırlama olmaksızın örfen 'arkadaş' denebilecek ölçüde uzun bir süre Hz. Peygamber'le beraber olmuş ve ondan ilim almış kimseye denir. ${ }^{3}$ Bu tarife göre Râşid halifeler, İbn Abbas, Zeyd b. Sabit, Hz. Aişe gibi tarifteki vasfı taşıyan kimselerin sahâbî olduğu anlaşılır. ${ }^{4}$ Sahâbe, fetvâlarına müracaat edilen, ictihadın kaynağı kimselerdi. Hz. Peygamber'in vefatından sonra ortaya çıkan olaylarla ilgili ihtilafları halletme işini sahâbe üstlenmiş oldu. Onların birçok meselede bazen ittifak bazen de ihtilaflı olarak vermiş oldukları fetvâlar çeşitli hadis ve fıkıh kitaplarında dağınık bir şekilde ilk devir alimleri tarafından bize intikal ettirilmiştir. Sahâbîlerden 160 kadarı fetvâ vermiş bulunmaktadır. ${ }^{5}$ Hanefî uleması sahâbe denilince bu şekilde dinde görüş beyan etme ehliyetine sahip, fikhıyla şöhret kazanmış fakih sahâbîleri kastetmişlerdir. ${ }^{6}$ Nitekim Abdülaziz elBuhârî (ö. 730/1330) açıkça "Sözünün hüccet değeri tartışılan sahâbeden maksat onların tamamı değil sadece fakih olanlarıdır."7 demiştir.

Ebû Hanîfe' den sözü hüccet sayılacak sahâbî hakkında üç farklı rivayet nakledilmiştir. Bunlardan birine göre Ebû Hanîfe, "her sahâbînin taklid edilmesi ve sözünün kıyasa takdim edilmesi vâciptir" derken diğer bir rivayete göre "sadece sözü kıyasa uygun olan sahâbînin taklit edilmesi vâciptir" demiştir. Ebü'l-Hasen el-Kerhî ile birlikte bir grup usûlcü bu görüşe meyletmişlerdir. Diğer bir rivayette ise "sahâbeden sadece fakih olanlarını taklid etmek vâcip, diğerlerini taklit etmek vâcip değildir" demiştir. Ebû Saîd el-Berdaî ile Hanefîlerin çoğunluğu bu görüşe meyletmişlerdir. ${ }^{8}$ Ebû Hanîfe'ye nispet edilen bu ifadelere ilk döneme ait Hanefî fıkıh usûlü eserlerinde rastlanılmamaktadır. Dolayısıyla bunların

Alâuddîn Abdülaziz b. Ahmed el-Buhârî, Keşfü'l-esrâr an usûli Fahri'l-İslâmel-Pezdevî̂̀, Kâhire, Dâru'l-kitâbi'l-İslâmî, ts. c. 2, s. 385; Sa'düddin Mes'ud b. Ömer et-Taftazânî, Şerhu't-Telvîh ale't-tavzih li metni't-Tenkîh fî usûli'l-fikh, tahk.: Zekeriyya Umeyrât, Beyrut, 1996, c. 2, s. 10; İbn Emîru Hâc, et-Takrîr ve't-tahbîr fì usûli'l-fikh, Beyrut, Dâru'l-kütübi'l-ilmiyye, 1996, c. 1, s. 15. Benzer tanım için bk. Ebü'l-Muzaffer Mansur b. Muhammed b. Abdilcebbâr es-Sem'ânî, Kavâtiü'l-edille fî'l-usûll, tahk.: Muhammed Hasan Muhammed Hasan İsmâîl eş-Şâfiî, Beyrut, Dâru'l-kütübi'l-ilmiyye, 1997, c. 1, s. 392; Ebû Hâmid Muhammed b. Muhammed Gazzâlî, el-Mustasfâ min ilmi'l-usûl, Beyrut, el-Mektebetü'l-asriyye, 2008, c. 1, s. 232.

4 Abdullah Çolak, İslâm Hukuk Tarihi ve İslâm Hukukunun Delilleri, Malatya, 2014, s. 312.

5 Mustafa Uzunpostalcı, “İlk İki Asırda Fıkıh”, SÜİFD., sayı: 2, Konya, 1986, s. 328; Çolak, İslâm Hukuk Tarihi ve İslâm Hukukunun Delilleri, s. 312-313.

6 Ebû Zeyd Ubeydullah b. Ömer ed- Debûsî, Takvîmü'l-edille fì usûli'l-fikh, tahk.: Halil Muhyiddin el-Müysü, Beyrut, Dâru'l-kütübi'l-ilmiyye, 2007, s. 257; Muhammed b. Ahmed b. Ebî Sehl es-Serahsî, el-Usûl, İstanbul, Kahraman Yayınları, 1984, c. 1, s. 338; Abdülaziz elBuhârî, Keşfü'l-esrâr, c. 3, s. 224.

7 Abdülaziz el-Buhârî, Keşfü'l-esrâr, c. 3, s. 224.

8 Abdülaziz el-Buhârî, Keşfü'l-esrâr, c. 3, s. 224. 
Ebû Hanîfe'nin uygulamalarından elde edilmiş çıkarımlar olması kuvvetle muhtemeldir.

Sahâbe kavli denilince, hakkında nas veya icmâ olmayan şer'î bir konuda her hangi bir sahâbîden nakledilen fetvâ veya hüküm kastedilir. ${ }^{9}$ Sahâbeden kendisini ehil görenler, kendilerine sorulan meseleler hakkında görüşlerini bildirmiş ve fetvâ vermişlerdir. Kendilerine bir konuda fetvâ sorulan sahâbîlerin verdikleri cevaplar da ittifakla aynı olabildiği gibi farklı da olabiliyordu. Onların ihtilaf ettikleri görüşlerin Kitap, Sünnet, icmâ ve kıyas gibi şer'î bir kaynak sayılıp sayılmayacağı konusunda ihtilaf edilmiştir.

İmam Ebû Hanîfe (ö. 150/767), İmam Ebû Yûsuf (ö. 182/798) ve İmam Muhammed (ö. 189/805) başta olmak üzere dört mezhebin kurucu imamlarıyla usulcülerin cumhuru ister akılla kavranabilecek konularda olsun isterse akılla kavranamayacak konularda olsun sahâbî sözünü hüccet olarak kabul etmişlerdir. İmam Mâlik (ö. 179/795) Kur'an ve Sünnet'te hakkında delil bulunmayan konularda sahâbe kavlini Sünnet gibi telakki etmiştir. ${ }^{10}$ İmam Şâfiî̀nnin (ö. 204/820) eski mezhebinde sahâbe kavlini hüccet saydiğı sonra bundan vazgeçtiği şeklinde yaygın bir kanaat olsa da onun yeni mezhebini içeren eserlerinin neredeyse tamaminda sahâbe kavlini hüccet kabul ettiğini gösteren ifadelerine ve uygulamalarına sıkça rastlamak mümkündür.11 Meselâ İmam Şâfiî, Mısır'da yeniden yazdı̆̆ı ve Rabi' b. Süleyman tarafından rivayet edilen er-Risâle adlı eserinde, "Kitap, Sünnet, icmâ veya bu anlamda hükme kaynak olacak bir delil bulamadığım zaman sahâbîlerden birinin sözüne göre hüküm veririm" demiştir. ${ }^{12}$ Bu ifade İmam Şâfiî’nin, sahâbenin icmâ ettikleri görüşleri aldığını, sahâbîler ihtilaf ederlerse onların sözlerinden Kitap ve Sünnet'e yakınlık bakımından en kuvvetli olanıyla amel etmeyi tercih ettiğini gösteriyor. ${ }^{13}$ İmam Ahmed (ö. 241/855) de sahâbî sözünü sika ravilerin rivayet ettiği mürsel hadisten ve kıyastan daha üstün kabul etmiştir. ${ }^{14}$ Buradan bütün mezheb imamlarına göre sahâbî kavlinin Kur'an, Sünnet ve icmâ'dan sonra başvurulacak tâlî naklî kaynakların başında geldiği anlaşılıyor.

9 Musa İbrahim, el-Medhal ila usûli'l-fikh ve târihi't-teşrî́il-İslâmî, Amman, 1989, s. 65; Çolak, İslâm Hukuk Tarihi ve İslâm Hukukunun Delilleri, s. 313.

10 Recep Özdemir, "İmam Malik'in Metodolojisinde Sahabi Kavlinin Delil Değeri”, Türk-İslâm Medeniyeti Akademik Araştırmalar Dergisi, Y1l. 11, say1: 22, Konya, 2016, s. 205.

11 Taha Nas, “İmam Şâfiî̀nin Sahâbe Kavline Bakışı”, Artuklu Akademi Dergisi (Journal of Artuklu Academia), 2014/1 (1), s. 190-191.

12 Muhammed b. İdris eş-Şâfî̂, er-Risâle, tahk.: Ahmed Muhammed Şakir, Beyrut, ts. s. 598.

13 Muhammed Ebû Zehra, Usûlü'l-fikh, Beyrut, Dâru'l-fikr, 1958, s. 216.

14 Ebû Ya'lâ Muhammed b. Huseyn b. Muhammed el-Ferrâ, el-Udde fî usûli'l-fikh, tahk.: Ahmed b. Ali b. Seyyid el-Mübarekî, Riyad, 1990, c. 3, s. 909. 
Hanefî usulcüleri arasında akılla kavranamayacak konularda onlardan hiç birinin muhalefeti bilinmeyen sahâbî kavliyle amel etmenin vacip olduğu konusunda herhangi bir ihtilaf bulunmamaktadır. Aynı şekilde akılla bilinebilecek konularda sahâbîlerin üzerinde ittifak ettikleri re'ye dayanan sözleri sahâbe icmâ'ı sayılacağından bu tarz sahâbî kavline uyulacağı konusunda da ihtilaf yoktur. Akılla kavranabilecek konularda üzerinde ittifak edilmeyen sahâbî kavli konusunda ise Hanefî mezhebinde üç ana akımın olduğu görülmektedir.

Birincisi, kurucu imamların görüşleridir. Onlara göre akılla kavranabilecek konularda üzerinde ittifak edilmeyen sahâbî sözüyle amel etmenin vacip değil, caiz olduğu anlaşılmaktadır.

İkincisi, fazla meşhur olmasa da Hanefî usulünde önemli bir yeri olan Berdaî’nin görüşüdür. Berdaî, akılla kavranamayacak konularda olduğu gibi akılla bilinebilecek konularda da sahâbî kavliyle amel etmenin mutlak vacip olduğu görüşünü benimsemiştir. Ona göre sahâbîler, aralarında ihtilaf etmiş olsa bile onlardan birinin sözünü tercih etmek vaciptir. Berdaî bu görüşünü subûtu tartışmalı bir kısım rivayetlere ve aklî gerekçelere dayandırmıştır. Ondan sonra gelen Hanefî usulcülerin çoğunluğu da mezkûr delilleri sıhhat ve delalet yönünden tenkide tabi tutmadan tekrar ederek her nevi sahâbî kavliyle ameli vacip saymışlardır.

Üçüncüsü, Ebü'l-Hasen el-Kerhî’nin görüşüdür. Kerhî, mekâdîr-i şer'iyye (şer'î miktarlar) gibi akıl ve re'y ile kavranamayacak konular dışında sahâbî kavliyle amel etmenin caiz olmadığı görüşünü benimsemiştir. ${ }^{15}$ Kerhî de görüşünü ispat için naklî ve aklî bir takım delillere dayanmıştır.

Biz bu çalışmamızda önce Hanefî mezhebi imamlarına isnat edilen rivayetler ve fıkhî çözümlemeleri ışığında onların sahâbe kavliye ilgili görüşlerini tespite çalışacağız. Ardından Ebû Saîd el-Berdaî ve Ebü'l-Hasen el-Kerhî ile onlara tabi olan Hanefî usûlcülerin görüşlerini ve delillerini ele alarak onlar üzerinde bir değerlendirme yapacă̆ız.

\section{Sahâbî Kavli Konusunda Hanefî Mezhebi Imamlarinin Görüşleri}

Sahâbî kavli konusunda Ebû Hanîfe' den intikal eden bazı rivayetler bulunmakla birlikte onların sübûtu hakkında Hanefî usûlcüler ihtilafa düşmüşle- 
rdir. Ebü'l-Hasen el-Kerhî, sahâbî kavli ile ilgili olarak Ebû Hanîfe'nin sadece şöyle dediğini söylemiştir: "Sahâbe bir konu üzerinde icmâ ettiği zaman onlarn bu icmâ'ın kabul ederiz. Tâbiûn icmâ ettiği zaman onlarla yarışırız."16 Kerhî'ye göre Ebû Hanîfe'den sahâbî kavli konusunda bundan başka sağlam yollarla bir söz gelmemiştir. ${ }^{17}$ Ancak Yahyâ b. Maîn (ö. 233/848), İbn Ebi'l-Avvâm (ö. 335/947), Beyhakî (ö. 458/1066), İbn Abdülber (ö. 463/1072) ve Herevî (ö. 481/1089) ittifakla Ebû Hanîfe'ye kadar ulaşan senetlerle onun şöyle dediğini rivayet etmişlerdir: "Kur'an'da bir hüküm bulduğum zaman onu alırım. Kur'an'da bulamadığım zaman Resîlüllahıın Sünneti'ni alırım. Allah'ın Kitabı'nda ve Resûlüllah'ın Sünneti'nde bulamadığım zaman ashâbının sözlerine başvururum. Onlardan dilediğim kimsenin sözünü alır, dilediğimin sözünü terk ederim fakat onlarn sözlerinden dışarı çıkıp başkalarının sözünü almam." ${ }^{18}$ Bu ifadelerden Ebû Hanîfe'nin, hakkında nass bulamadığı konularda delil olmaya elverişli gördüğü sahâbî kavlini hüccet saydığı fakat sahâbe dışındakilerin görüşlerinin kendisini bağlayıcı bir delil olmayacağı kanaatinde olduğunu gösterir.

Yine İbn Ebi'l-Avvâm ve Beyhakî̀nin kendi senetleriyle rivayet ettiklerine göre Ebû Hanîfe'nin öğrencilerinden İbnü'l-Mübârek (ö. 181/797), Ebû Hanîfe'nin şöyle dediğini duymuştur: "Peygamber'den gelirse başımızla gözümüz üzerinedir (alır kabul ederiz). Peygamber'in ashâbından gelirse onlarm sözleri arasında tercih yaparız. Tâbiûndan gelirse onlar da insan biz de insanız."19 Ebû Hanîfe' nin bu ifadesinden de sahâbe arasında ihtilaf olması halinde onların görüşleri arasında tercih yapılabileceği fakat onların sözünün dışına çıkılmayacağı anlaşılmaktadır. Dolayısıyla bu ifadesiyle yukarıdaki ifadesi birbirini tamamlamakta ve prensip olarak hakkında nass bulunmayan konularda sahâbî kavlini hüccet saydı̆̆ı anlaşılmaktadır. Ancak Serahsî (ö.

16 Cessâs, el-Fusûl fî'l-usûl, c. 3, s. 361; Debûsî, Takvîmü̈l-edille, s. 256; Serahsî, el-Usûl, c. 1, s. 313; Semerkandî, Mîzânü'l-usûul, c. 2, s. 697.

17 Cessâs, el-Fusîl fî'l-usûl, c. 3, s. 361; Debûsî, Takvîmü'l-edille, s. 256; Serahsî, el-Usûl, c. 1, s. 313; Semerkandî, Mîzânü'l-usûl, c. 2, s. 697.

18 Yahya b. Maîn Ebû Zekeriye, Târihu Yahya b. Maîn, tahk.: Ahmed Muhammed Nur Seyf, Mekketü'l-Mükerreme, 1979, c. 4, s. 63; İbn Ebi'l-Avvâm Ebü'l-Kâsım Abdullah b. Muhammed b. Ahmed b. Haris es-Sa'dî, Fedâilü Eb̂̂ Hanîfe ve ahbâruhu ve menâkıbuh, tahk.: Latîfü'r-Rahmân el-Behrâicî el-Kâsımî, Mekketü'l-mükerreme, el-Mektebetü'l-imdâdiyye, 2010, s. 98; Ahmed b. El-Hüseyin b. Ali b. Musa el- Beyhakî, el-Medhal ilâ Süneni'l-kübrâ, tahk.: Muhammed Ziyâu'r-rahmân el-A'zamî, Kuveyt, Dârul-hulefâu li'l-kitâbi'l-İslâmî. ts., c. 1, s. 203; Ebû Ömer Yûsuf b. Adillah b. Muhammed b. Abdilber, el-İntifâ' fî fedâili'sselaseti'il-eimmeti'l-fukahâ Mâlik ve'ş-Şâfî̀ ve Eb̂̂ Hanîfe, Beyrut: ts., s. 144,145; Ebû İsmail Abdullah b. Muhammed b. Ali el- Herevî, Zemmü'l-kelâm ve ehlih, tahk.: Abdurrahman Abdülaziz eş-Şebel, el-Medinetü'l-münevvere, 1998, c. 5, s. 101. İbn Ebi'l-Avvâm, Fedâilü Ebî Hanîfe, s. 97; Beyhakî, el-Medhal, c. 1, s. 111. 
483/1090) dışında ilk dönem Hanefî usûlcüleri eserlerinde bu rivayetlere yer vermedikleri gibi Cessâs (ö. 370/981), Debûsî (ö. 430/1039) ve Semerkandî (ö. 539/1145) sahâbîyi taklid konusunda Ebû Hanîfe'den zâhir bir rivayetin bulunmadığını söylemişlerdir. ${ }^{20}$

Serahsî ise, Ebû Hanîfe'nin, "Bize sahâbeden gelirse onlara tabi oluruz, tabiûndan gelirse onlarla yarışırız." ifadesini el-Usîl' ünde rivayet etmiş ve bu sözün Ebû Hanîfe'ye ait olduğunu teyit etmiştir. ${ }^{21}$ Keza Abdülalî el-Leknevî (ö. 1225/1810), Abdülhak ed-Dihlevî’nin (ö. 1052/1642) Fethu'l-mennân fî te'yîdi mezhebi'n-Nu'mân adlı eserinden naklen Ebû Hanîfe'nin, "Peygamberden gelirse başımızla gözümüz üzerinedir (alır kabul ederiz). Ashâbından gelirse onu terk etmeyiz." dediğini ve onun bu sözünün sahâbeyi taklid konusunda sarih bir nass (açık bir söz) olduğunu fakat bazı meselelerdeki amelinin sahâbî kavline muhalif olduğunu, bunun da muhtemelen başka bir sahâbî sözüyle tearuz sabit olmasından kaynaklandığını söylemiştir. ${ }^{22}$ Aynı şekilde İbn Hüsrev el-Belhî el-Hanefî (ö. 522/1128) başta olmak üzere müteahhirûn Hanefî usûlcülerden birçoğu yukardaki haberleri eserlerinde rivayet etmişler $^{23}$ ve herhangi bir eleştiriye yer vermemişlerdir. Bu da onların bu rivayetlerin sıhhati konusunda şüphe etmedikleri anlamına gelmektedir.

Cessâs, Debûsî ve Pezdevî gibi ilk dönem Hanefî usûlcülerin gerek kendileriyle aynı dönemde gerekse daha önce yaşamış olan birçok müellifin farklı senetlerle naklettikleri bu rivayetleri eserlerine almamaları onların muhtemelen Kerhî’nin tesirinde kaldıklarını göstermektedir. Zira Ebû Hanîfe'nin fıkhî çözümlemelerine bakıldığında, bunların yukardaki rivayetlerle örtüştüğü görülecektir. Mesela Ebû Hanîfe, hayzın en az müddetinin üç gün, en fazla

20 Cessâs, el-Fusûl, c. 3, s. 361; Debûsî, Takvîmü'l-edille, s. 256; Semerkandî, Mîzanü'l-usûll, c. 2, s. 697.

21 Serahsî, el-Usîul, c. 1, s. 313.

22 Abdülalî Muhammed b. Nizamüddin el- Leknevî, Fevâtihu'r-rahmût bi şerhi Müsellemi'ssübût, neş.: Abdullah Mahmud Muhammed Ömer, Beyrut, Dâru'l-kütübi'l-ilmiyye, 2002, c. 2 , s. 234 .

23 İbn Hüsrev Ebû Abdullah el-Hüseyin b. Muhammed b. Hüsrev el-Belhîel-Hanefî, Müsnedü'lİmam el-A'zam Eb̂̂ Hanîfe en-Nu'mân b. Sâbit, tahk.: Latîfü'r-Rahman el-Behrâicî el-Kâsımî, Mekketü'l-Mükerreme: el-Mektebetü'l-imdâdiyye, 2010, c. 1, s. 161; Salahuddin Ebû Saîd Halil b. Abdillah ed-Dimeşkî el- Alâî, İcmâlü'l-isâbe fî akvâli's-sahâbe, tahk.: Muhammed Süleyman el-Aşkar, Kuveyt, Dâru ihyâi't-türâsi'l-İslâmî, 1407, s. 80; İbn Emîru Hâc, et-Takrîr ve't-tahbîr fî ilmi'l-usûl, c. 2, s. 415; Leknevî, Fevâtihu'r-rahamût, c. 3, s. 384; Ebü'l-Hasenât Abdülhayy b. Muhammed el- Leknevî, en-Nâfiu'l-kebîr şerhu'l-Câmii's-sağîr, Beyrut, 1986, s. 44; Muhammed el- Hudârî, İslâm Hukuku Tarihi, çev.: H. Hatipoğlu, İstanbul, Kahraman Yayınları, 1974, s. 238. Ebû Zehra, Usûlü'l-fikh, s. 215; Abdüvahhâb el-Hallâf, İslâm Hukuk Felsefesi, çev.: Hüseyin Atay, Ankara, 1973, s. 248. 
süresinin ise on gün olduğunu söylemiş ve bunu Enes ve Osman b. Ebi'lÂs es-Sakafî' den rivayet etmiştir. ${ }^{24}$ Osman b. Ebi'l-Âs es-Sakafî’nin kavli sebebiyle nifas (lohusalık)ın en fazla süresini kırk gün olarak belirlemiştir. ${ }^{25}$ Keza çocuğun ana rahminde iki seneden fazla kalamayacağı konusunda Hz. Aişe'nin kavliyle amel etmiştir. ${ }^{26}$ Aynı şekilde "Bir kimse bedelini üç güne kadar ödemediği takdirde aralarında alışveriş olmamış sayılmak şartıyla bir şey satın alsa kıyasa göre akit fasittir fakat biz İbn Ömer'den rivayet edilen eser sebebiyle bu kıyası terk ettik", demiştir. ${ }^{27}$

Ebû Hanîfe'nin fıkhî çözümlemelerini inceleyen Hanefî usûlcüler de re'y ile kavranamayacak bu gibi konularda muhalifi bilinmeyen sahâbe kavliyle amel konusunda Ebû Hanîfe'nin tatbikatlarının birleştiği sonucuna varmışlardır. ${ }^{28}$ Hanefî usûlcülere göre Ebû Hanîfe'nin bu uygulamalarının sebebi bu meseleler hakkındaki sahâbî kavillerinin Hz. Peygamber'den işitmeye dayanmasıdır. Zira re'y ile kavranamayacak meseleler ve şer'î miktarlar konusunda re'y ile görüş beyan etmeye imkân olmadığından sahâbeden hiç birinin bu konularda zan ve tahminle görüş beyan ettiği düşünülemez. $\mathrm{Bu}$ durumda Hz. Peygamberden işitmiş oldukları ortaya çıkar ve fetvaları mutlak olarak Peygamber'den rivayet gibi kabul edilir. Dolayısıyla kıyasa uymayan konularda sahâbeden bir kişinin kavli amel etme yönünden nass gibi hüccet olur ve kıyasa takdim edilir. Ancak kıyas ve re'y ile bilinebilecek meselelerde sahâbî kavli ile amel konusunda Ebû Hanife'nin uygulamaları farklılık arzetmektedir. Ebû Hanîfe bu nevi sahâbe kavliyle kimi durumlarda amel ederken kimi durumlarda da sahâbî kavlini terk ederek kendi re'y ve içtihatlarıyla onların aksi yönünde fetva vermiştir. Mesela Câbir b. Abdillah (ö. 78 / 697) ve Abdullah b. Mes'ûd (ö. 32 / 652), hamile kadının sünnete binaen bir defadan fazla boşanamayacağını söylemişler fakat Ebû Hanîfe Câbir b. Abdillah ve İbn Mes'ûd'a muhalefet etmiştir. ${ }^{29}$ Keza Ebû Hanîfe re'y ile Hz.

Cessâs, el-Fusûl, c. 3, s. 364; Pezdevî, Usûlü'l-Pezdevî, c. 3, s. 218; Serahsî, el-Usûl, c. 2, s. 110. Cessâs, el-Fusûl, c. 3, s. 364; Abdülaziz el-Buhârî, Keşfü'l-esrâr, c. 3, s. 218.

Cessâs, el-Fusîl, c. 3, s. 364-365; Serahsî, el-Usûl, c. 2, s. 110; Serahsî, el-Mebsût, Beyrut, Dâru'l-fikr, 1993, c. 17, s. 160.

Serahî, el-Mebsût, c. 13, s. 17.

8 Ebû Zeyd Ubeydullah b. Ömer ed-Debûsî, Te'sîsü'n-nazar, tahk.: Mustafa Muhammed el-Kabbânî ed-Dımeşkî, Beyrut, Mektebetü'l-külliyeti'l-ezher, ts., s. 113; Ebü'l-Hasan Ali b. Muhammed el-Pezdevî, Usulü'l-Pezdevî (Abdülaziz el-Buhârî'nin Keşfü'l-esrâr an Usûli fahri'l-İslâm el-Pezdevî adlı şerhi içinde), Kâhire: Dâru'l-kitabi'l-İslâmî, ts., c. 3, s. 218; Serahsî, el-Usîl, c. 2, s. 110.

9 Debûsî, Takvîmü'l-edille, s. 256; Serahsî, el-Mebsût, c. 6, s. 10. 
Ali'ye muhalefet ederek ecîr-i müşterekin ${ }^{30}$ yanında zâyi' olan eşyayı tazmin etmeyeceğini söylemiştir. ${ }^{31}$ Aynı şekilde âyise (âdetten kesilen) kadına ve hayız görmeyen kız çocuğuna kıyas ederek hamile kadınının Sünnet'e binaen üç kere boşanacağını söylemiştir. Çünkü onun doğuruncaya kadar hayız görmesi beklenmez. Fakat Câbir b. Abdillah ve İbn Mes' ûd'dan bunun aksini söyledikleri rivayet edilmiştir. ${ }^{32}$

Bu çözümlemeler Ebû Hanîfe'nin akıl ve re'y ile kavranabilecek konularda sahâbî kavlini mutlak hüccet görmediği, onları kendi içtihadıyla uyuşan durumlarda alıp uyuşmayan durumlarda terk ettiği anlamına gelmektedir. Ebû Hanîfe muhtemelen bu gibi durumlarda kendi içtihadına uygun sahâbî kavline vakıf olduğu zaman içtihadını sahâbî kavliyle teyid etmek istemiş olabilir. Şu örnekler bu düşünceyi doğrular niteliktedir:

Ebû Hanîfe, selemin caiz olması için anaparanın önceden belirlenmesini şart koşmuş ve bu sözün İbn Ömer'den ulaştığını söylemiştir. ${ }^{33}$ Mazmaza ve istinşak konusunda şöyle demiştir: "Bunların ikisi de cünüplük ve abdestte, kıyasa göre sünnettir. Biz İbn Abbas'ın (ö. 68/687-688) kavlinden dolayı kıyası terk ettik."34 Keza yaranın başında görülen ve akmayan kan konusunda "Bu kan kıyasa göre abdesti bozar fakat İbn Abbas'ın kavlinden dolayı biz kıyası terk ettik." demiştir. ${ }^{35}$ Bayılma konusunda da; "Bayginlık bir gün bir gece veya daha az sürdüğ̈̈ zaman, kıyasa göre bu, namazların kaza edilmesine manidir. Fakat biz Ammar b. Yasir'in bir gün bir gece baygın kaldıktan sonra namazı kaza ettiğine dair rivayeti sebebiyle kıyası terk ettik." demiştir. ${ }^{36}$

Gerek sahâbî kavlini terk ederek re'y ve içtihadıyla hüküm verdiğini gerekse sahâbî kavli sebebiyle kıyası terk ettiğini ifade eden bu uygulamalar ilk dönem usûlcüler tarafından Ebû Hanîfe'nin kıyas yoluyla kavranabilecek konularda sahâbe kavli konusunda sabit bir görüşünün olmadığını gösteren bir delil olarak kabul edilmiştir. ${ }^{37}$ Gerçekte Ebû Hanîfe bu konuda bağlayıcı

30 Ecîr-i müşterek; boyacı ve çamaşırcı gibi ancak iş yapmakla ücrete hak kazanan işçi demektir.

31 Debûsî, Takvîmü'l-edille, s. 256; Serahsî, el-Mebsût, c. 15, s. 160.

32 Abdülaziz el-Buhârî, Keşfü'l-esrâr, c. 3, s. 218.

33 Abdülaziz el-Buhârî, Keşfü'l-esrâr, c. 3, s. 218.

34 Serahsî, el-Usûl, c. 2, s. 105-106.

35 Serahsî, el-Usûl, c. 2, s. 106.

36 Cessâs, Fusûl, c. 3, s. 361; Serahsî, el-Usûul, c. 2, s. 106.

37 Pezdevî, Usûlü'l-Pezdevî, c. 3, s. 217; Serahsî, el-Usûl, c. 2, s. 106; Abdülaziz el-Buhârî, Keşfü'lesrâr, c. 3, s. 217-218. 
bir usûl benimsemese de sahâbe icmâ‘' ve kıyas yoluyla kavranamayacak meseleler dışında kalan sahâbî kavlini de mutlak olarak reddetmediği aksine birçok konuda sahâbî kavli sebebiyle kıyası terk edip ona uyduğu anlaşılıyor. Ebû Hanîfe'ye göre bir müçtehidin kendisinden daha fakih olan bir âlimin görüşünü taklit etmesi caiz olduğu için, hakkında nass bulunmayan konularda mutmain olduğu zaman sahâbî kavline, mutmain olmadığı zaman da sahâbî kavlini terk ederek kendi içtihadına göre fetva vermiştir. Bundan Ebû Hanîfe'nin, akıl ve re'y ile bilinebilecek meselelerde sahâbeyi taklit etmeyi vâcip değil, caiz gördüğü sonucu çıkmaktadır. ${ }^{38}$

Ebû Yûsuf'a gelince; Kerhî onun, bir meselenin hükmünü beyan ederken çoğu kez; "(Bu meselede) kıyas şöyledir ancak ben eserden dolayı kıyası terk ettim. Bu eser başka sahâbîler tarafindan muhalefet edildiği bilinmeyen sahâbî kavlidir.". ${ }^{39}$ dediğini rivayet etmiştir. Ebû Yûsuf'un bu ifadesinden de akılla kavranamayacak konularda muhalifi bilinmeyen sahâbî kavliyle ameli vacip gördüğü anlaşılmaktadır. Aksi halde kıyası terk edip sahâbî kavliyle amel etmesi izah edilemez.

Kerhî'nin beyanına göre İmam Muhammed de sahâbî kavli konusunda şöyle demiştir: "Fikıh dört şey üzerine bina edilir. Bunlar: Kur'an'da mevcut olan, Hz. Peygamberden mütevatir ve meşhur olarak rivayet edilen Sünnet, Sahâbenin üzerinde icmâ' ettiği ve hakkmda ihtilafa düştü̈̆̈ü görüşler ve Müslümanlarm güzel gördüğ̈̈ şeylerdir." ${ }^{40}$ Cessâs'a göre İmam Muhammed bu ifadesiyle sahâbenin icmâ‘nı Kitap ve Sünnet gibi hüccet ve asıl kabul etmiştir. Sahâbenin ihtilafa düştükleri şeylerle de onlar bir mesele hakkında ihtilaf ettikleri zaman hiçbir kimsenin onların sözlerinin tamamının dışına çıkıp sahâbîlerden hiç birinin söylemediği yeni bir söz ortaya koyma hakkının olmadığını kastetmiştir. ${ }^{41}$ Ancak İmam Muhammed'in tatbikatları Cessâs'ın bu çıkarımını desteklememektedir. Zira Hanefî furû' kitaplarına bakıldığında gerek İmam Ebû Yûsuf'un gerekse İmam Muhammed'in hakkında sahâbe kavli bulunan birçok meselede onlara aykırı fetva verddikleri görülecektir. Meselâ İmam Ebû Yûsuf ile İmam Muhammed (kıyasla amel ederek selemde işaret edildiği zaman)

38 Bu konuda bk. Hacı Yunus Apaydın, "Sahâbî Sözünün Hukukî Değeri”, Erciyes Üniversitesi Sosyal Bilimler Enstitüsü Dergisi, 1990, s. 330.

39 Cessâs, el-Fusîl fî'l-usûl, c. 3, s. 361; Debûsî, Takvîmü'l-edille, s. 256; Serahsî, el-Usûl, c. 1, s. 313; Ebû Bekir Alâuddin Muhammed b. Ahmed b. Ebû Ahmed es-Semerkandî, Mîzânü'lusûl fî netâici'l-'ukûl, tahk.: Abdülmelik Abdurrahman es-Sa'dî, Mekketü'l-mükerreme, Vüzâratü'l-evkâf, 1987, c. 2, s. 697.

40 Cessâs, Fusûl, c. 3, s. 271; Serahsî, el-Usûl, c. 1, s. 318.

41 Cessâs, Fusûl, c. 3, s. 271. 
re'sü'l-mâlin (anaparanın) miktarını (sözle) belirtmenin şart olmadı̆̆ını söylemişlerdir. Halbu ki İmam Muhammed, İbn Ömer'den (ö. 73 / 692) bunun aksini rivayet etmiştir. ${ }^{42}$ Ebû Yûsuf ile İmam Muhammed ücretle insanların elbiselerini muhafaza eden elbisecinin ecîr-i müşterek konumunda olduğunu ve korunması mümkün olmakla birlikte yanındaki elbise çalındığı zaman onu tazmin edeceği görüşünü benimsemişler ve bu görüşü $\mathrm{Hz}$. Ali'den rivayet etmişlerdir. $^{43}$

Sonuç olarak mezheb imamlarının sahâbî kavli hakkındaki görüşleriyle ilgili olarak şunu söyleyebiliriz: Onlar sahâbe icmâ'1 ve şer'î miktarlarda olduğu gibi re'y ile kavranamayacak konularda muhalifi bilinmeyen sahâbî kavliyle ameli vâcip, rey'le bilinebilecek konularda sahâbî kavliyle ameli caiz görmüşlerdir. Hanefîlerin şer'î miktarlarla kast ettikleri, hadd-i zina, hadd-i kazf, hadd-i sirkat, namazın rek'atlerinin sayısı vb. gibi sırf Allah hakkı olan hadler ve ibadetlerle ilgili miktarlardır. Bunun dışında normal yollarla baliğ olmayan çocuğun hükmen baliğ kabul edilmesinin üst sınırının onsekiz yaş olması, çocuğun rüşt çağına ulaşmadığı zaman yirmibeş yaşına ulaşıncaya kadar malının kendisine verilmemesi gibi rey ve içtihatla bilinebilecek miktarlar konusunda nakle dayalı olmaksızın fetva vermişlerdir. ${ }^{44}$

\section{Hanefî Usûlcülerin Sahâbî Kavli Konusundaki Görüşleri}

Hanefî usûlcüler, ister imam (devlet başkanı), ister hâkim ve isterse müfti olsun sahâbî sözünün başka bir sahâbî için hüccet teşkil etmeyeceği konusunda ittifak etmişlerdir. ${ }^{45}$ Onların tartışmaları sahâbî kavlinin tâbiûn ve onlardan sonra gelen müçtehitler için hüccet teşkil edip etmeyeceği noktasındadır. Hanefî usûlcülerin ifadelerinin geneline bakıldığında onların tartışmalarının şu beş kısım sahâbî kavli üzerinde yoğunlaştığı görülür:

a. Sahâbe İcmâ' 1

b. Mekâdîr-i şer'iyye (şerıî miktarlar) gibi akıl ve re'y ile kavranamayacak konularda muhalifi bilinmeyen sahâbe kavli

42 Pezdevî, Usûlü'l-Pezdevî, c. 3, s. 217; Abdülaziz el-Buhârî, Keşfü'l-esrâr, c. 3, s. 217-218.

43 Debûsî, Takvîmü'l-edille, s. 256; Serahsî, el-Mebsût, c. 15, s. 160.

44 Cessâs, Fusûl, c. 3, s. 365-366; Abdülaziz el-Buhârî, Keşfü'l-esrâr, c. 3, s. 230.

45 Abdülaziz el-Buhârî, Keşfü'l-esrâr, c. 3, s. 217; Muhammed b. Ferâmûz Molla Hüsrev, Mir'âtü'l-usûl Şerhu Mikâti'l-vüsûl, tahk.: İlyas Kaplan et-Türkî, Beyrut, Dâru Sâdır, 2011, s. 313; İbn Melek İbn Firişte İzzeddin Abdullatif, Şerhu Menâri'l-envâr fì usûli'l-fikh, İstanbul, Salah Bilici Kitabevi, ts., s. 252; İbn Nüceym Zeynüddin Zeyn b. İbrâhim b. Muhammed, Fethü'l-gaffâr bi-şerhi'l-Menâr, Beyrut, Dâru'l-kütübi'l-ilmiyye, 2001, s. 347. 
c. Akıl ve re'y ile bilinebilecek konulardaki sahâbî kavli

d. Sahâbenin ihtilafı

e. İhtilaf ettikleri de ittifak ettikleri de bilinmeyen sahâbî kavli

\subsection{Sahâbe İcmâ'1}

Mütekaddimûn ve müteahhirûn devri Hanefî hukukçuları sahâbe icmâ‘ının kesin olarak bağlayıcı olduğu ve kendilerinden sonra gelen bütün müçtehitler için hüccet teşkil edeceği konusunda ittifak etmişlerdir. Hatta Cessâs ile Serahsî, İmam Muhammed'e göre üzerinde icmâ' meydana gelen sahâbe kavlinin, kat'îlik bakımından Kitap ve Sünnet ile sabit olan hüküm mesabesinde olduğunu, bu icmâ'ın kesin ilim ifade ettiğini ve onu inkâr eden kimsenin Kitap ve mütevatir hadisle sabit olanı inkâr eden kimse gibi tekfir edileceğini söylemişlerdir. ${ }^{46}$ Pezdevî (ö. 482/1089) de bu görüşü benimseyerek sahâbe icmâ'ının, amel etmenin vücubu ve bilgi bakımından ayet ve mütevatir hadis gibi olduğunu ve onu inkâr edenin tekfir edileceğini söylemiştir. ${ }^{47}$ Hanefî usûlcülerin büyük çoğunluğu da sahâbe arasında yaygınlık kazanıp diğerlerinin de kabul etmesi halinde sahâbî sözünün icmâ' yerine geçeceği için taklit edilmesininin vâcip olduğu görüşünü benimsemişlerdir. ${ }^{48}$

\subsection{Akıl ve Re'y ile Kavranamayacak Konularda Muhalifi Bilinmeyen Sahâbî Kavli}

Akıl ve re'y ile kavranamayacak konularda muhalifi bilinmeyen sahâbî kavlinin tâbiûn ve daha sonra gelen müçtehitler için hüccet teşkil edeceği konusunda mütekaddimûn ve müteahhirûn Hanefî hukukçuları ittifak halindedirler. ${ }^{49}$ Sahâbî kavlinin mutlak hüccet olduğu görüşünü benimseyenlerin başında gelen Ebû Saîd el-Berdaî herhangi birisinin muhalefet ettiği

46 Cessâs, Fusûl, c. 3, s. 271; Serahsî, el-Usûl, c. 1, s. 318.

47 Pezdevî, Usûlü'l-Pezdevî, c. 3, s. 261-262.

48 Sadruşşerîa, Tenkîhu'l-usûl, s. 36-37; İbn Melek, Şerhu Menâri'l-envâr, s. 253; Molla Hüsrev, Mir'âtü'l-usûl, s. 313; İbn Nüceym, Fethu'l-gaffâr, s. 348.

49 İbnü's-Saâtî Ahmed b. Ali b. Tağleb b. Ebi'z-Ziyâ, Nihâyetü'l-vüsĥll ilâ ilmi'l-usûl, neş.: Hasan İsber ve İbrahim Şemsüddin, Beyrut, Dâru'l-kütübi'l-ilmiyye, 2004, s. 275; Ebü'l-Berekat Hafızüddin Abdullah b. Ahmed b. Mahmûd en-Nesefî, Menâru'l-envâr (İbn Melek'in şerhi içerisinde), İstanbul, Salah Bilici Kitabevi, ts., s. 252; Molla Fenârî Şemsüddin Muhammed b. Hamza b. Muhammed, Fusûlü'l-bedâi' fî usûli'ş-şerâi', tahk.: Muhammed Hasan Muhammed Hasan İsmâil, Beyrut: Dâru'l-kütübi'l-ilmiyye, 2006, c. 2, s. 434-438; Molla Hüsrev, Mir'âtü'lusûl Şerhu Mikâti'l-vüsûl, s. 313; İbn Nüceym, Fethu'l-gaffâr, s. 347; Leknevî, Fevâtihu'rrahamût, c. 2, s. 233. 
bilinmediği zaman sahâbî kavli sebebiyle kıyasın terk edileceği görüşünü benimsemiş ve "âlimlerimizi bu görüş üzerinde bulduk" demiştir. Ona göre Hz. Peygamber'i müşahade etmek suretiyle nasslarla açıklanan durumları bildiği için sahâbînin kıyası bizim kıyasımızdan daha kuvvetlidir. Zira yanında nass bulunan sahâbîlerin kendilerine soru sorulduğu sırada bazen bunu rivayet ettikleri bazen de rivayette bulunmaksızın mutlak olarak nassa uygun fetva verme alışkanlığında oldukları ortaya çıkmıştır. Hz. Peygamber'den işitilme ihtimali olan fetvanın sırf re'ye takdim edileceğinde şüphe yoktur. Bu sebeple sahâbî kavlinin mücerret re'ye takdim edilmesi haber-i vahidin kıyasa takdim edilmesi mesabesinde olur. ${ }^{50}$

Aynı şekilde Ebü'l-Hasen el-Kerhî de akıl ve içtihad yoluyla ispat edilmesine imkân olmayan şer'î miktarlar (mekâdîr-i şer'iyye) konusunda sahâbî kavliyle amel edilmesini vâcip kabul ederek bu görüşü mezheb imamlarına nispet etmiştir. ${ }^{51}$ Kerhî́ye göre de bu miktarları içtihad ve kıyas yoluyla ispat etmemize imkân olmadığına ve bunun yolunun Peygamber'den işitme veya icmâ' olduğuna göre sahâbînin bu konuda kesin hüküm verdiğini gördüğümüz zaman bu durum onu Peygamber'den işiterek söylemiş olduğuna delalet eder. Çünkü onların bu sözü zan ve tahminde bulunarak söylediklerini düşünmek caiz değildir. Sadece bu vasıfta olan şer'î miktarlar konusundaki sahâbî kavlini kabul etmek ve işitmeye dayanması yönünden ona ittiba etmek vâciptir. ${ }^{52}$ Debûsî de Hanefî mezhebinin dayandığı prensipleri bir araya getirdiği Te'sisü'n-nazar adlı eserinde şöyle demiştir: "Âlimlerimiz nazarında asıl (kaide); onlardan hiçbir kimse muhalefet etmediği zaman sahâbî kavlinin kıyastan önce geleceğidir. Çünkü kıyasa aykırı olduğu için sahâbî bu sözü kıyas yoluyla söylemiştir denilmesi mümkün değildir. Bunu zan ve tahmin yürüterek söylemiştir denilmesi de caiz değildir. Şu halde zahir olan onun bu sözü Hz. Peygamber'den işiterek söylemiş olduğudur." 53

Şu halde Hanefî usûlcüler arasındaki ihtilaf; prensip olarak akıl ve re'y ile bilinebilecek konulardaki sahâbî sözü ile sahâbenin ihtilafının tâbiûn müçtehidleri ve onlardan sonra gelenler için hüccet teşkil edip etmeyeceği noktasında toplanmaktadır. Bu noktada Hanefî usûlcüler Ebû Saîd el-Berdaî ve Ebü'l-Hasen el-Kerhı̂’nin başını çektiği iki farklı görüşe sahip olmuşlardır.

50 Cessâs, Fusûl, c. 3, s. 361; Debûsî, Takvîmü'l-edille, s. 256; Serahsî, el-Usûl, c. 2, s. 105, 108; Pezdevî, Usûlü'l-Pezdevî, c. 3, s. 217, 222-224.

51 Cessâs, Fusûl, c. 3, s. 364.

52 Cessâs, Fusûl, c. 3, s. 365.

53 Debûsî, Te'sîsü'n-nazar, s. 113. 


\subsection{Akıl ve $\operatorname{Re}^{\prime} y$ ile Bilinebilecek Konulardaki Sahâbî Sözü}

Hanefî usûlcüler tümevarım yöntemiyle yaptıkları araştırmalar sonucunda mezheb imamlarının akıl ve re'y ile bilinebilecek konularda sahâbe kavliyle amel konusunda sabit bir görüşlerinin olmadığı sonucuna varmışlardır. Bu usûlcüler mezheb imamlarının bu konulardaki tatbikatlarının delâletlerinin farklı olduğu; çözümlerden bazılarının sahâbî kavlinin kıyasa takdim edileceğine bazılarının da kıyasın sahâbî kavline takdim edileceğine delâlet ettiğini söylemişlerdir. ${ }^{54}$ Bu sebeple Hanefî usûlcüler akıl ve re'y ile bilinebilecek konularda sahâbî kavlinin tâbiûn ve onlardan sonra gelen müçtehidler için hüccet teşkil edip etmeyeceği konusunda görüş ayrılığına düşmüşlerdir.

\subsubsection{Ebû Saîd el-Berdaî'nin Görüşüi}

Ebû Saîd el-Berdaî (ö. 317/929), re'yle bilinebilecek konulardaki sahâbî kavlinin başkaları için Sünnet kapsamına gireceği için kendi re'yini terk edip sahâbîyi taklit etmesinin vâcip olduğu görüşünü benimsemiştir. ${ }^{55}$ İlk dönem Hanefî usûlcülerin çoğunluğu da Ebû Saîd el-Berdaî ile aynı görüşe sahip olmuşlardır. Bunlar görüşlerini şu iki gerekçeye dayandırmışlardır: Birincisi, sahâbînin sözünü, Peygamber'den işiterek söylemiş olma ihtimalidir. İkincisi bizatihi re'y konusunda isabetlerinin bizden daha fazla olması ihtimalidir. ${ }^{56}$ Ayrıca bunlara göre sahâbî sözü re`yden sadır olsa bile onların re`yi başkalarının re`yinden daha kuvvetlidir. Çünkü onlar hadiselerin hükümlerini beyan konusunda Resulüllah'ın takip ettiği yöntemi, hakkında nasların nâzil olduğu durumları ve kendileri sebebiyle hükümlerin değişmeyeceği mekânları müşahede etmişlerdir. Bu hususiyetleri itibariyle onların re'yleri bu tür hadiselerden hiç birini müşahede etmeyenlerin re' yine tercih olunur. ${ }^{57}$

Daha sonraki usûlcülerin çoğunluğu da bu görüşü benimsemiştir. Onlara göre de sahâbe bu fetvalarını verirken Hz. Peygamber'den rivayet etme ihtimali vardır. Zira onların yanında nass bulunduğu zaman bazen onu rivay-

55 Pezdevî, Usûlü'l-Pezdevî, c. 3, s. 222-223; Serahsî, el-Usûl, c. 2, s. 108; Molla Fenârî, Fusûlü'lbedâî', c. 2, s. 436; Leknevî, Fevâtihu'r-rahamût, c. 2, s. 231-232.

56 Pezdevî, Usûlü'l-Pezdevî, c. 3, s. 222-223.

57 Cessâs, Fusûl, c. 3, 362-363; Serahsî, el-Usûl, c. 2, 108; Pezdevî, el-Usûl, c. 3, s. 219, 222-223, 224; İbnü's-Saâtî, Nihâyetü'l-vüsûl, s. 275; Abdülaziz el-Buhârî, Keşfü'l-esrâr, c. 3, s. 27, 222223; İbn Melek, Şerhu Menâri'l-envâr, s. 252; Molla Fenârî, Fusûlü'l-bedâi', c. 2, s. 437-438; Ebü'l-Fidâ Zeynüddîn Kasım b. Kutluboğa el-Hanefî, Hulâsatü'l-efkâr şerhu Muhtasari'lMenâr, tahk.: Hâfız Senâullah ez-Zâhidî, Dâru ibn Hazm, 2003, s. 59. 
et edip bazen de rivayette bulunmaksızın mutlak olarak nassa uygun fetva verme âdetinde oldukları ortaya çıkmıştır. Şüphe yok ki kendisinde Hz. Peygamber'den işitme ihtimali olan fetva sırf re'ye takdim olunur. Bu yönden bir tek sahâbînin sözünü re'ye takdim etmek haber-i vâhidi kıyasa takdim etme mertebesindedir. ${ }^{58}$

Ebû Saîd el-Berdaî ve ondan etkilenen Hanefî usûlcüler mezheb imamlarından farklı olarak re'yle bilinebilecek konularda hatta aralarında ihtilaf ettikleri konularda bile sahâbî kavliyle amel etmenin vâcip olduğu görüşünü benimsemişlerdir. Halbuki Ebû Hanîfe'nin söz ve uygulamalarından onun sahâbe icmấı yanında kıyasa aykırı olan hususlarda muhalifi bilinmeyen sahâbî kavliyle ameli vâcip gördüğü diğer konularda ise sahâbî kavliyle ameli vâcip değil, caiz gördüğü sonucu çıkmaktadır. Buna göre Ebû Saîd el-Berdaî'den sonra Hanefî usûlcülerin çoğunluğunun akılla bilinebilecek konulardaki sahâbî kavliyle amel etme konusundaki görüşleri mezheb imamlarının görüşlerinden daha ileri bir boyuta evrilmiştir.

Berdaî ve onunla aynı görüşü paylaşanlar sahâbî kavliyle amel edilmesini mutlak vacip sayarken görüşlerini ispat etmek için naklî ve aklî bir takım deliller ileri sürmüşlerdir. Bu delillerin başlıcaları şunlardır:

\section{a. Âyetler:}

Bu görüş sahipleri ilk olarak şu ayetle istidlal etmişlerdir: "(İslâm dinine girme konusunda) öne geçen ilk muhâcirler ve ensâr ile onlara güzellikte tabi olanlar var ya işte Allah onlardan razı olmuştur, onlar da Allah'tan razı olmuşlardır. Allah onlara, içinde ebedî kalacakları, zemininden ırmaklar akan cennetler hazırlamıştır. İşte bu büyük kurtuluştur." 59

$\mathrm{Bu}$ ayette sahâbe ve onlara güzellikte uyanlar övülmektedir. Ancak bu övgü onların görüşlerine uyma sebebiyle değil, Kitap ve Sünnet'e uyma konusunda onların yolunu takip etme sebebiyledir. Bu âyetin umûmu sahâbeyi taklidin vâcip olduğunu ifade etse bile bu husus, onlardan sadır olup hakkında diğerlerinden muhalefet ortaya çıkmamış olan sahâbî kavli hakkın-

58 Pezdevî, Usûlü'l-Pezdevî, c. 3, s. 219; Serahsî, el-Usûl, c. 2, s. 108; Hüseyin b. Ali b. Haccâc b. Ali Hüsâmüddin es- Signâkî, el-Kâfî fî Şerhi'l-Pezdevî, tahk.: Fahruddin Seyyid Muhammed Gânit, Kâhire, 2001, c. 4, s. 1583-1584; Abdülaziz el-Buhârî, Keşfü'l-esrâr, c. 3, s. 223-224; İbn Emîru Hâc, et-Takrîr ve't-tahbîr, c. 2, s. 415; İbn Kutluboğa, Hulâsatü'l-efkâr, s. 59; İbn Melek, Şerhu Menâri'l-envâr, s. 252; İbn Nüceym, Fethu'l-gaffâr, s. 347. 
da geçerli olabilir. Hakkında ihtilaf edilen sahâbî kavline gelince bu övülmeyi hak edecek bir konu değildir. Çünkü bazısına ittiba etmekle övgü hak edilirse bazısına uymayı terk etmekle de yergi hak edilir, dolayısıyla çelişki meydana gelmiş olur. Bu sebeple nass, aralarında ihtilaf meydana gelmeyen durumlarda onları taklit etmenin vücûbu konusunda delil olur. ${ }^{60}$ Meselâ dede ile kızkardeşlerin mirasçı olmaları meselesinde Hz. Ebû Bekir (ö. 13/634), Hz. Ömer (ö. 23/644), Hz. Ali (ö. 40/661) ve Hz. Aişe'nin (ö. 58/678) farklı görüşler ortaya koydukları bilinmektedir. ${ }^{61}$ Bunların hepsine birden uymaya imkan olmadığından delile dayanmadan herhangi birinin sözüne uymayı vacip saydığımızda ona uymakla vacibi eda ederken diğerlerinin sözünü terk etmekle de vacibi terk etmiş oluruz. Vacibi terk etmek ise caiz değildir.

Bu görüşteki usûlcülerin ikinci delilleri şu ayet-i kerimedir: "Siz insanların iyiliği için ortaya çıkarılmış en hayırlı ümmetsiniz; iyiliği emreder, kötülükten mender ve Allah'a inanirsiniz..." 62

$\mathrm{Bu}$ ayet sahâbîlerin tamamını ifade etmektedir. Ayette ifade edildiği gibi onların tamamı mârufu emrettikleri zaman bu icmâ anlamına geldiği için ona uymak vâcip olur. Buradaki ihtilaf, onlardan birinin tek başına sözünün delil olup olmayacağı noktasındadır. Dolayısıyla bu ayet birer birer sahâbî sözlerine uymanın vâcip olacağına delil teşkil etmez. Fakat hakkında nass bulunmayan konularda daha sağlam bir delil olmadığı müddetçe sahâbî sözüne uymanın vâcip değil, caiz olduğunu söylemek mümkündür.

\section{b. Hadisler}

$\mathrm{Bu}$ usûlcüler görüşlerine birtakım hadisleri delil göstermişlerdir. Bunların başında şu hadisler gelmektedir:

"Benim ve benden sonraki râşid halifelerin sünnetine sarılınız." ${ }^{33}$ ve "Benden sonra şu iki kişiye; Ebû Bekir ve Ömer'e uyunuz"64

Bu hadislerden, sahâbe ihtilaf etmediği zaman onları taklidin gerekli olduğu anlaşılır. Zira aralarında ihtilaf ettikleri meselelerde onlara ittiba etmek

60 Semerkandî, Mîzânü'l-usûl, c. 2, s. 702; İbn Emîru Hâc, et-Takrîr ve't-tahbîr, c. 2, s. 415.

61 Ebû Muhammed Ali b. Ahmed b. Saîd b. Hazm, el-İhkâm fî usûli'l-ahkâm, tahk.: Mahmud Hâmid Osman, Kâhire, Dâru'l-hadîs, 2005, c. 6, s. 848.

62 Âl-i İmran, 3/110.

63 Tirmizî, Sünen, "İlim”, 44; Ebû Davud, Sünen, "Sünne”, 13-14; Ahmed, Müsned, c. 4, s. 126.

64 Tirmizî, Sünen, "Menâkıb”, 16, 37; İbn Mâce, Sünen, "Mukaddime”, 11; Ahmed, Müsned, c. 5, s. 382, 385, 399, 402. 
vâcip değil ancak caiz kabul edilebilir. Nitekim Cessâs'a göre sahâbeden hiç kimse muhalefet etmeksizin ikisi bir görüşte birleştikleri zaman onları taklit vâcip olur. Onlar bir görüşte birleştiklerinde taklit edilmeleri vâcip olunca başkasının muhalefet ettiği bilinmediği zaman ikisinden birini ve sahâbeden herhangi birini taklit etmek de vâcip olur. Ancak hadis, diğer sahâbîler kendilerine muhalefet ettiği zaman onları taklidin vâcip olmadığına delalet eder. ${ }^{65}$

Hz. Peygamber'den sonra raşid halifelerin aralarında birçok konuda ihtilaf meydana geldiği bilinmektedir. Bu hadisleri raşit halifelerin sözlerine uymamız gerektiği şeklinde anladığımızda onların aralarında ihtilaf ettikleri görüşlerin hepsiyle amel etmemiz gerekir ki buna imkân yoktur. Diğer taraftan onların Peygamber'den işitmedikleri ve aralarında ittifak bulunmayan sözlerine uyulmasını vâcip saymak Hz. Peygamber'den sonra yeni bir hüküm kaynağı ortaya koymak anlamına gelir. Bu ise tıpkı diğer kaynaklarda olduğu gibi bir delile dayanmadan mümkün değildir. Ayrıca onlardan birinin görüşünü aldığımız zaman, diğerinin görüşünü terk etmiş oluruz. Bu durumda da onların sünnetine tabi olmamış ve mezkûr hadisin hilafına hareket etmiş oluruz. ${ }^{66}$

Şu halde bu hadisler üç şekilde yorumlanabilir: Birincisi, bu hadislerde Ebü'l-Hasen el- Kerhî ile Debûsî'nin de belirttiği gibi hakkında nass bulunmayan konularda re'y ve içtihada başvurma hususunda onların yolunun takip edilmesi kastedilmektedir. ${ }^{67}$ İkincisi, onların Resulüllah'ın Sünnet'lerine tabi olmaları, onunla fetva vermeleri ve diğer sahâbîlerin onlarla görüş birliği etmeleri halinde raşit halifelerin sözlerine uymanın vâcip olduğudur. Üçüncüsü, Hz. Peygamber bununla insanlara, râşit halifelere boyun eğmelerini, itaat etmelerini ve hükümlerini geçersiz saymamalarını ve Hz. Peygamber' in sîretine bağlılıkları hususunda onların takip ettikleri yolu takip etmelerini emretmiş olmalıdır. ${ }^{68}$

Bunların diğer bir delilleri de şu hadistir: "Ashâbım yıldızlar gibidir, hangisine uyarsaniz hidayete ermiş olursunuz"69

66 Bu konuda bk. İbn Hazm, İhkâm, c. 6, s. 848 vd.

67 Debûsî, Takvîmü'l-edille, s. 258; Serahsî, el-Usûl, c. 2, 107.

68 Gazzâlî, el-Mustasfâ, c. 1, s. 303.

69 Cessâs, Fusûl, c. 3, s. 363; İbn Hazm, İhkâm, c. 5, s. 680. 
Ahmed b. Hanbel (ö. 241/855) bu hadisin sahih olmadığını, ${ }^{70}$ İbn Hazm (465/1074) uydurma, yalan ve batıl bir haber olduğunu, ${ }^{71}$ İbn Abdilber de hadisin ravisi Hâris b. Gusayn meçhul bir kimse olduğu için senedinin hüccet teşkil etmeyeceğini söylemiştir. ${ }^{72}$ Hanefî âlimlerden İbn Ebi'l-'İz (ö. 792/1391) de Bezzâr'dan (ö. 292/905) naklen bunun Resulüllah'tan geldiğisahiholmayan ve güvenilir hadis kitaplarında mevcut olmayan zayıf bir haber olduğunu belirtmiştir. ${ }^{73}$ Dolayısıyla bu hadis sahâbî kavlinin hüccet olduğuna delil teşkil etmez. Ayrıca sahâbenin her biri hidayet kaynağı olsaydı onlar birbirlerini hata etmekle itham etmez, birbirlerine karşı çıkmazlar ve onlardan biri kendi görüşünden vazgeçip arkadaşının görüşüne uymazdı. Meselâ İbn Abbas ile Misver b. Mahreme (ö. 64/683) ihramlının başını yıkayıp yıkayamayacağı konusunda ihtilafa düşmüşler ve bu konuda Ebvâ denilen yerde aralarında tartışma çıkmıştı. Misver, ihramlı kimsenin başını yıkayamacağını söylerken İbn Abbas bunun aksini iddia ediyordu. Bunun üzerine İbn Abbas görüşünü ispatlamak için Ebû Eyyüb el-Ensârî’ye (ö. 49/669) haber gönderip ondan Hz. Peygamber'in ihramlı iken başını yıkayıp yıkamadığını haber vermesini istedi. Ebû Eyyup el-Ensârî de Hz. Peygamber'in ihramlı iken başını yıkadığını gördügünü haber verdi. ${ }^{74}$ Bunun üzerine Misver kendi görüşünden vazgeçip İbn Abbas'ın görüşüne uydu ve ona "seninle ebediyyen tartışmayacağım" dedi. Eğer mezkûr hadisteki "iktidâ"dan maksat onların sözlerine uymak olsaydı, İbn Abbas, Misver'e "sen de yıldizsin ben de yildızım, bizden sonrakiler hangimize uyarsa onlara kifayet eder" der ve sözüne delil getirme ihtiyacı duymazd. ${ }^{75}$ Yukardaki hadisi sahih saysak bile sahâbeye uymaktan maksat onları taklit konusunda uymak değil, hükümler konusunda doğruyu araştırmada onların metodları üzerinde yürümektir. Onların metodları ise re'y ve içtihatla amel etmekti. Bu durumda onların delile dayanan ve aralarında ittifak ettikleri sözlerine uymak gerekir. Re'y ve içtihada dayanan bir tek sahâbî sözüne uymak vâcip olmaz. Ancak hakkında nass bulunmayan konularda daha sağlam bir delil olmadığı zaman sahâbî sözü alınabileceği gibi terk de edilebilir. Nitekim

70 Muhammed Nâsıruddin Elbânî, Silsiletü'l-ehâdîsi'd-dâ̂fe, c. 1, s. 78-79.

71 İbn Hazm, İhkâm, c. 5, s. 681; 6, s. 852-853.

72 Ebû Ömer Yûsuf b. Abdillah b. Abdilber, Câmiu beyâni'l-ilm vefadlih, tahk.: Ebû Abdurrahman Fevvaz Ahmed Zümerlî, Dâru İbn Hazm, 2003, c. 2, s. 183.

73 İbn Ebi'l-İz Sadruddîn Muhammed b. Alâuddîn Ali b. Muhammed el-Hanefî, Şerhu'lakîdeti't-Tahâviyye, Mektebetü'l-İslâmî, 2005, s. 468-469.

74 Hadis için bk. Buhârî, es-Sahîh, "Sayd", 14; Müslim, es-Sahîh, "Hacc", 91; Ebû Davud, Sünen, "Menasik", 37.

75 Ahmed b. Ali b. Hacer el-Askalânî, Fethu'l-bârî bi şerhi Sahîhi'l-Buhârî, tahk.: Muhammed Fuad Abdülbâkî-Muhibbüddin el-Hatîb, Kâhire, Dâru'l-beyân li't-türâs, 1986, c. 4, s. 68. 
Hakem b. Uteybe ve Mücâhid, "Allah Resûlünden sonra Allah'ın kulları arasında sözlerinden bazısı alınıp bazısı terk edilmeyecek hiç kimse yoktur." demişlerdir. ${ }^{76}$

Bu usûlcülerin dayandıkları hadislerden biri de şudur: "Yıldızlar semânın emniyetidirler. Yıldızlar gitti mi semâya vadolunan şeyler gelir. Ben ashâbım için bir emniyetim. Ben gittim mi ashâbıma vadolunan şeyler gelir. Ashâbım da ümmetim için bir emniyettir. Ashâbım gitti mi ümmetime vadolunan şeyler gelir."77

Hâkim bu hadisi "Yıldızlar gök ehlinin emânıdırlar. Yıldızlar kaybolduğu zaman onlara vadolunan şeyler gelir. (Aralarında) bulunduğum müddetçe ben de ashâbımın emânıyım. Ben gittiğim zaman onlara vadolunan şeyler gelir. Ehli beytim de ümmetimin emânıdırlar. Ehli beytim gittiği zaman onlara vadolunan şeyler gelir." 78 şeklinde rivayet etmiş ve isnadının sahih olduğunu fakat Buhârî ve Müslim'in onu rivayet etmediklerini belirtmiştir. ${ }^{79} \mathrm{Bu}$ hadislerde sahâbîlerin kavline uymanın vâcip olacağına dair bir delil yoktur. Gazzâlî’nin (505/1111) de belirttiği gibi bu hadislerin hepsi, sahâbenin ilimleri, dinleri ve Allah katındaki mevkileri hususunda hüsnüzan beslemeyi gerektirir, onları taklit etmenin caiz veya vâcip olmasını gerektirmez. ${ }^{80}$ Ancak Kur'an ve Sünnet'e uymaları konusunda onların takip ettikleri yolu takip etmeyi gerektirir.

Bunların bir diğer delilleri de Hz. Peygamber'in şu hadisidir: "Insanların en hayırlısı benim muasırlarım, sonra onları takip edenlerdir, sonra onları takip edenlerdir." ${ }^{81} \mathrm{Bu}$ hadis de sahâbenin ilim, vera ve takvada üstünlükleri hakkında bir övgü olup onların sözlerine uymayı gerektirmez. ${ }^{82}$

\section{c. Aklî Gerekçeler}

Bu görüş sahiplerinin aklî gerekçeleri şudur: "Sahâbenin fetva verirken Peygamber'den işiterek fetva verdikleri fakat soru sorulduğu zaman sadece hükmü söy-

76 İbn Abdilber, Câmiu beyâni'l-ilm ve fadlih, c. 2, s. 183-184. Ayrıca bk. Ali Arslan, Hadiste Metin Tenkidi Prensibi Olarak Tarihe-Vakıaya Aykırılık, Kastamonu, 2013, s. 92-103.

77 Müslim, "Fedâilü's-sahâbe”, 51; Süleyman b. Ahmed b. Eyyub et- Taberânî, el-Mu'cemü'levsat, tahk.: Tarık b. Ivazullaah b. Muhammed-Abdülmuhsin b. İbrahim el-Huseynî, Kâhire, ts., c. 7, s. 6; a.mlf. el-Mu'cemü's-sağîr, tahk.: Muhammed Şekûr Mahmud el-Hâc, Beyrut, Dâru'l-kütübi'l-ilmiyye, 1985, c. 2, s. 166.

78 Hâkim Ebû Abdillah el-Hâkim Muhammed b. Abdillah en-Nisâbûrî, el-Müsredrek ale'sSahîhayn, tahk.: Mustafa Abdulkâdir Atâ, Beyrut, Dâru'l-kütübi'l-ilmiyye, 1990, c. 2, s. 486.

79 Hâkim, el-Müsredrek ale's-Sahîhayn, c. 2, s. 486.

80 Gazzâlî, Mustasfâ, c. 1, s. 305.

81 Buhârî, "Şehâdât", 9; "Fedâilü ashâbi'n-nebî̀, 1; Tirmizî, "Fiten”, 45; "Menâkıb”, 56.

82 Gazzâlî, Mustasfâ, c. 1, s. 305. 
leyip yanlarında mevcut olan hadisi çoğu zaman rivayet etmedikleri ortaya çıkmıştır. Dolayısıyla sahâbenin sözlerine uymak gerekir." Bu gerekçe de isabetli görünmemektedir. Zira sahâbîlerin her zaman Peygamber'den işiterek fetva verdiklerini söylemek onlardan rivayet edilen fetvalarla uyuşmamaktadır. Hanefîler sahâbeyi tezkiye etmek amacıyla böyle bir görüşe meyletmişlerdir. Halbu ki onların Peygamber'den işiterek fetva verdikleri gibi kendi re'yleriyle fetva verdiklerini gösteren pek çok ifadelerine rastlamak mümkündür. Meselâ Hz. Ebû Bekir'e Kur'ân-1 Kerim'de geçen “'الكلالة" lafzının ne anlama geldiği sorulunca şu cevabı vermiştir: "Bu hususta kendi görüşümü söyleyeceğim. Doğru ise Allah'tan yanlış ise benden ve şeytandandır. "Kelâle", ölenin baba ve oğlu dışında kalan mirasçılarıdır." 83

İbn Sîrîn'den (ö. 110/729) rivayete göre şöyle demiştir: “Hz. Peygamber'den sonra bilmediği şeyi söylemekten Ebû Bekir'den daha fazla korkan kimse yoktu. Ebû Bekir'den sonra bilmediği şeyi söylemekten Ömer'den daha fazla korkan kimse yoktu. Ebû Bekir'e bir mesele arzedildiğinde o konuda Allah'ın Kitabı'nda bir asıl ve Peygamber'in Sünneti'nde bir eser bulamadığı zaman re'yi ile içtihad eder ardından şöyle derdi: 'Bu benim görüşümdür. Şayet doğru ise Allah'tan, yanlış ise bendendir, ben Allah'tan bă̆ışlanmamı dilerim." 84

Hz. Ömer, verdiği hükmü yazan kâtibi “Bu, Allah'ın ve Ömer'in uygun gördüğü hükümdür." diye yazınca şöyle demiştir: "Ne kötü şey söyledin! 'Verdiği hüküm doğru ise Allah'tan yanlış ise Ömer'dendir, de!" $85 \mathrm{~Hz}$. Ömer'in bu ifadesi onun hüküm verirken her zaman elinde mevcut olan bir habere dayanarak değil kendi içtihadına göre de hüküm verdiğini göstermektedir.

Hz. Ömer'e kocası kendisinden iki yıl uzakta kalmış ve döndüğünde hamile olduğu görülmüş bir kadın şikâyet edildi. Bunun üzerine Hz. Ömer kadına recm cezası uygulamak istedi. Muaz (ö. 17/638) şöyle diyerek Ömer'e karşı çıktı: "Ey mü'minlerin emiri! O kadın hakkında ceza uygulama hakkın varsa da karnındakine ceza uygulaman için bir gerekçen yoktur." Bunun üzerine Hz. Ömer kadını bıraktı. Sonunda kadın ön dişleri çıkmış bir erkek çocuk doğurdu. KoRiyâd: 1409, c. 6, s. 298.

84 İbn Abdilber, Câmiu beyâni'l-ilm ve fadlih, c. 2, s. 111; İbn Hazm, el-İhkâm, c. 6, s. 827.

85 İbn Hazm, İhkâm, c. 6, s. 825; İbnü'l-Kayyım, Şemsüddîn Ebû Abdillah Muhammed b. Ebî Bekir el-Cevziyye, I'lâmü'l-muvakkı'în 'an rabbi'l-âlemin, tahk.: Muhyiddin Abdülhamid, Beyrut, Dâru'l-fikr, 1977, c. 1, 39. 
cası çocuğun kendisine benzediğini anladı. Hz. Ömer de şöyle dedi: "Kadınlar Muaz gibisini doğuramaz. Muaz olmasaydı Ömer helak olmuştu!"86

Hz. Ömer, "Diyet âkıleye $e^{87}$ aittir, kadın kocasının diyetine mirasçı olamaz." diyordu. Fakat Dahhâk b. Süfyân el-Kilâbî (ö. 11/632 ?) Hz. Peygamber'in kendisine Eşyem b. Dabâbî'nin diyetinden karısına da miras payı ayrılmasına dair yazılı talimat gönderdiğini haber verince Ömer bu görüşünden vazgeçip hadise uydu. ${ }^{88}$

Beyhakî'nin (ö. 458/1067) Hişâm b. Yahyâ el-Mahzûmî'den rivayet ettiğine göre Sakîf'ten bir adam Hz. Ömer'e gelip daha önce Kurban bayramı günü ziyaret tavafını yapmış olan ve âdet görmeye başlayan kadının temizlenmeden Mekke'yi terk edip edemeyeceğini sordu. Hz. Ömer "Terk edemez" dedi. Sakîf'li adam, "Hz. Peygamber bana böyle bir kadın hakkında senin verdiğin fetvanın aksi yönde fetva vermişti." deyince Hz. Ömer şiddetli tepki gösterdi ve şöyle dedi: "Allah Resûlü'nün hüküm verdiği mesele hakkında niçin benden fetvâa istiyorsun?!" 89

Hz. Ali insanlara hutbe irad ederken "Hz. Ömer, Ümmühât-ı evlâd olan câriyeler hakkında benimle istişare etti. Ömer ile ben onların azad edilecekleri görüşünde birleştik. Ömer ve Osman hayatları boyunca buna göre hüküm verdiler. Ben halife olunca onların köle edinilmeleri görüşünü benimsedim." dedi. Bunun üzerine Ubeyde es-Selmânî; "Ömer ile Ali'nin birlikte benimsedikleri görüş bize Ali'nin tek başına kaldığı görüşünden daha sevimlidir." cevabını verdi. ${ }^{90}$

İbn Mes'ûd mihir belirlemeden bir kadını nikâhlayıp zifafa girmeden önce vefat eden bir kimse hakkında kendisine sorulan bir soruya cevap vermek istediğinde "Bu konuda tamamen re'yimle görüş beyan edeceğim. Şayet isabet edersem bu ortağı olmayan Allah'tandır. Hata edersem benden ve şeytandandır. Allah ve Resûlü bundan beridirler." demiştir. ${ }^{91}$

Abdürrezzak Ebû Bekir Abdürrezzak b. Hemmâm es-San'ânî, el-Musannef, tahk.: Habîbü'rrahmân el-A‘zamî, Beyrut: 1987, c. 7, s. 354-355; İbn Ebî Şeybe, el-Musannef, c. 5, s. 543.

87 Âkıle: İslâm hukukunda, kasıtlı olmaksızın adam öldürme fiilini veya ağır bir müessir fiili işleyen kimsenin ödeyeceği diyeti üstlenmesi gereken yakınları (yahut mensup olduğu meslekî teşekkülü) ifade eder.

88 İbn Ebî Şeybe, c. 5, s. 416.; Ebû Davud, Sünen, "Ferâiz", 18; Tirmizî, Sünen, "Diyât"; İbn Mâce, Sünen, "Diyât", 12.

89 Beyhakî, el-Medhal ilâ süneni'l-kübrâ, c. 1, s. 104.

90 Saîd b. Mansûr, Sünen-i Saîd b. Mansûr, tahk.: Habîbürrahman el-A'zamî, Beyrut, Dâru'lfikr, 1985 , c. 2 , s. 60 .

91 İbn Hazm, İhkâm, c. 6, s. 824-825. 
$\mathrm{Bu}$ örnekler sahâbenin fetva verirken her zaman kendilerince malum olan fakat fetva anında rivayet etmedikleri bir sünnete dayanmadıklarını, çoğu zaman kendi re'yleriyle içtihad edip fetva verdiklerini ve zaman zaman içtihatlarında hata ettiklerini anlayınca kendi görüşlerinden vazgeçtiklerini göstermektedir. Sahâbî bir insandır ve hatadan masum değildir. Sonraki müçtehitlerin hata etmesi mümkün olduğu gibi onların da hata etmeleri mümkündür. $\mathrm{Bu}$, onlar için bir nakîsa teşkil etmez. ${ }^{92}$ Zira müçtehid isâbet de eder hata da eder. Dolayısıyla sahâbî içtihad ederken bir delilden hareket etmişse onlardan sonra gelen müçtehidin bu delili öğrenip ona ittiba etmesi gerekir. Aksi halde sahâbînin mücerret re'yine uyması gerekmez. Zira müçtehidin, bir mesele ile karşılaştığında hakkı bulmak için bütün gücünü harcaması ve içtihadının sonunda hata ettiği ortaya çıkmadıkça kendi içtihadına göre amel etmesi vâciptir. ${ }^{93}$ Buna mukabil delilini bilmeden başka bir müçtehidi taklit etmesi câiz değildir. ${ }^{94}$

Hanefî mezhebi imamlarının ifadelerinden onların da bu görüşte olduğu anlaşılmaktadır. Nitekim Ebû Hanîfe, Ebû Yûsuf ve Züfer b. Hüzeyl (158/775) ittifakla "Delilimizi bilmedikçe hiç kimsenin bizim görüşümüzü benimseyip onunla fetvâ vermesi helâl değildir." 95 derken müçtehidin mücerret re'yine değil, deliline tabi olunacağını ifade etmişlerdir. Bu hususta sahâbîlerle diğer müçtehidler eşittir. Ebû Hanîfe, arkadaşlarını kendilerine ulaşan her şeyi kabul etmeye değil, bilakis mesele kendilerince iyice açığa çıkıncaya kadar ellerinden geleni ortaya koymaya teşvik etmiştir. Bu sebeple onlar delili açığa çıkan fetvaları kabul eder, delili sahih olmayan fetvaları terk ederlerdi. ${ }^{96}$ Dolayısıyla herhangi bir sahâbînin fetvası doğru ile yanlış arasında mütereddit olunca böyle bir görüss sebebiyle kıyas ve re'yin terk edilmesi caiz değildir. ${ }^{97}$ Aynı zamanda sahâbîlerden yapılan nakillerin tıpkı hadislerde olduğu gibi sübut Üniversitesi İlahiyat Fakültesi Dergisi, Y1l: 18, sayı: 29, 2013, s. 126.

93 Serahsî, el-Usûl, c. 1, s. 278, 296; Semerkandî, Mîzânü'l-usûl, c. 2, s. 1050.

94 Semerkandî, Mîzânü'l-usûl, c. 2, s. 1050.

95 Ebü'l-Leys Nasr b. Muhammed b. Ahmed es-Semerkandî, Uyûnü'l-mesâil, tahk.: Selâhaddîn en-Nâhî, Bağdat, 1966, s. 485; Cemâlüddîn Ebû Muhammed Abdullah b. Yûsuf ez-Zeylaî, Nasbu'r-râye li ehâdîsi'l-Hidâye, Kâhire, Dâru'l-hadîs, ts., c. 1, s. 38; Molla Fenârî, Fusûlü'lbedâi', c. 2, s. 495; Leknevî, Fevâtihu'r-rahamût, c. 2, s. 435.

96 Zeylaî, Nasbu'r-râye li ehâdîsi'l-Hidâye, c. 1, s. 38.

97 Serahsî, el-Usîl, c. 2, s. 107. 
sorununa açık oluşu ${ }^{98}$ da bir vakıadır. Dolayısıyla delilini bilmeden sahâbî sözünü merfu-sahih hadis derecesine yükselterek ona uymanın vâcip olduğunu söylemek isabetli gözükmemektedir.

\subsubsection{Ebü'l-Hasen el-Kerhî'nin Görüşüi}

Ebü'l-Hasen el-Kerhî́ye (ö. 340/952) göre re'y ve kıyas yoluyla bilinebilecek konularda sahâbînin hata etmesi mümkün olduğundan taklit edilmesi caiz değildir. ${ }^{99}$ Zira hakkında içtihadda bulunulması geçerli ve ispatında kıyasın rolü olan konularda sahâbî kavli hüccet değildir. Bu nevi sahâbî kavli hüccet olsaydı, -Kitap ve Sünnet uyulması gereken bir hüccet olduğu için hiç kimsenin muhalefet etmesi caiz olmadığı gibi-, aynı asırda yaşayan başka insanların ona muhalefet etmesi caiz olmazd1. ${ }^{100}$

Debûsî'nin de bu görüşe meylettiği anlaşılmaktadır. Ona göre sahâbenin bu tarz görüşü vahiyle değil, nassla sabit olan şer'î deliller üzerinde düşünme ve inceleme ile hüccet olmuştur ve bu görüş yanılma ihtimali taşır. Bundan dolayı onlar birbirlerine muhalefet ederler ve onlardan biri kendi fetvasından vaz geçip diğerinin fetvasına uyardı. Onlardan müçtehid olan biri şöyle derdi: "Hata etmişsem şeytandandır." Hata ihtimali olunca kesin olarak taklit edilmesi gereken bir hüccet olmaz. Nasslar üzerinde derinlemesine düşünmekle onlar için görüş beyan etmek caiz olunca nasslar kendisine ulaşan ve onların manaları üzerinde akıl yoran sahâbe ve diğerleri eşittir. Nitekim onlar nassın te'vilinde ihtilafa düştükleri zaman sahâbeden başkalarının te'viline başvururlardı. Çünkü bu yoruma dilin manalarına vukufiyetle ulaşılıyordu. Bu hususta da onlarla diğerleri eşittir. ${ }^{101}$ Abdülaziz el-Buhârî, Molla Fenârî (ö. 834/1431) ve Leknevî isim belirtmeksizin Hanefî âlimlerden bir grubun da bu görüşü benimsediğini söylemekte ${ }^{102}$ iseler de kaynaklarda İbnü'l-Hümâm (ö. 861/1457) dışında bu görüşü benimseyen başka bir usûlcüye rastlanılmamaktadır. İbnü'l-Hümâm diğer sahâbîlerin üzerinde ittifak ettikleri de hakkında

Ahmed Yaman ve Halit Çalış, İslâm Hukukuna Giriş, İstanbul, İFAV Yayınları, 2012, s. 48; Arslan, Ali, "Râvinin Rivâyetine Muhâlif Amel Etmesi Konusunun Hadis Usûlü ve Hanefî F1kıh Usûlü Eserlerinde Ele Alınışı", Akademik Sosyal Araştırmalar Dergisi, sayı: 5, 2017, s. 93-97.

99 Cessâs, Fusûl, c. 3, s. 361-362; Debûsî, Takvîmü'l-edille, s. 256; Pezdevî, Usûlü'l-Pezdevî, c. 3, s. 217; İbnü's-Saâtî, Nihâyetü'l-vüsûl, 275; Abdülaziz el- Buhârî, Keşfü'l-esrâr, c. 3, s. 217.

100 Cessâs, Fusûl, c. 3, s. 363.

101 Debûsî, Takvîmü'l-edille, s. 257.

102 Abdülaziz el-Buhârî, Keşfü'l-esrâr, c. 3, s. 217; Molla Fenârî, Fusûlü'l-bedâi', c. 2, s. 437; Leknevî, Fevâtihu'r-rahamût, c. 2, s. 232. 
ihtilaf ettikleri de bilinmeyen hususlarda, mesele akıl ve re' yle bilinemeyecek şeylerden değilse tercih edilen görüşe göre sahâbîyi taklidin vâcip olmadı̆̆ını söylemiştir. ${ }^{103}$ Ancak onun bu ifadesinden üzerinde ittifak edilmeyen sahâbî kavliyle ameli vâcip görmediği sonucu çıkmakla beraber caiz görmediği sonucu çıkarılamaz. Şu halde Debûsî ve İbnü'l-Hümâm'ın bu ifadeleri istisna edilirse, Kerhî́nin akıl ve re'y ile kavranamayacak konular dışında sahâbîyi taklidin caiz olmayacağı görüşünde neredeyse yalnız başına kaldığını söylememiz yerinde olur. Ancak Kerhî de görüşünü ispat etmek için birtakım aklî ve naklî deliller ileri sürmüş olup bunlar şöyledir:

\section{a. Ayetler}

Kerhî, başta şu ayetle istidlal etmiştir: "Ey akıl sahipleri ibret alınız"104

Ona göre bu ayetteki ibret almaktan maksat hakkında nass bulunmayan konularda kıyas ve rey ile amel etmektir. ${ }^{105}$

Onun diğer bir delili de şu ayet-i kerimedir: "Bir konuda anlaşmazliğa düşerseniz onu Allah'a ve Resulüne havale ediniz."106

Bu ayetin anlamı anlaşmazlıklarınızı Allah'ın Kitabına ve Resûlü'nün Sünneti'ne havale ediniz demektir. Muaz b. Cebel hadisi de buna delâlet etmektedir. Resulüllah, Muaz'a "Ne ile hükmedeceksin" demiş. Muaz; "Allahın kitabı ile" demiştir. Hz. Peygamber, "Allahın kitabında bulamazsan?" diye sormuş. Muaz; "Resulüllahın Sünneti'yle" demiştir. "Resulüllah'ın Sünneti'nde de bulamazsan ne ile hükmedeceksin?" dediğinde, Muaz "re'yimle içtihad ederim" demiştir. Bunun üzerine Hz. Peygamber "Resûlünün elçisini resulünün hoşnut olacă̆ı hükme muvafık kılan Allah'a hamdolsun" demiştir. Bu hadis, Kitap ve Sünnet'ten sonra rey'den başka amel edilecek bir kaynak olmadığına delildir. ${ }^{107}$

\section{b. Sahâbe Kavilleri}

Kerhî”ye göre Hz. Ömer, Kâdı Şüreyh'e (ö. 80/699 [?]) yazdığı mektupta "Allah'ın kitabıyla hüküm ver, onda yoksa Resulüllah'ın Sünnneti'yle hüküm ver

103 İbnü'l-Hümâm Kemâlüddîn Muhammed b. Abdülvahid es-Sivâsî, Fethu'l-kadîr, Beyrut, Dâru'l-kütübi'l-ilmiyye, ts., c. 10, s. 100.

104 el-Haşr, 59/2.

105 Serahsî, el-Usûl, c. 2, s. 106.

106 en-Nisâ, 4/115.

107 Serahsî, el-Usûl, c. 2, s. 106. 
onda da yoksa kendi re'yinle hüküm ver" demiş benim görüşümle hüküm ver dememiştir. ${ }^{108}$ Kadı Şüreyh de, Hz. Hasan'ın (ö. 49 / 669) Hz. Ali lehinde şahitlik yapmasını reddederek Hz. Ali'ye muhalefet etmiştir. Bu rivayetler sahâbî kavliyle amel etmenin vâcip olmadığını göstermektedir. ${ }^{109}$

\section{c. Aklî Deliller}

Kerhî̃ye göre sahâbe hata ve yanlıştan masum değildir. Bu sebeple sahâbînin kendi görüşünden dönüp başkasının görüşüne uyması caizdir. Aynı şekilde başka bir sahâbînin kendisine muhalefet etmesi de caizdir. ${ }^{110}$ Rivayete göre Mesrûk (ö. 63/683 [?]), oğlunu kurban etmeyi nezreden kimsenin nezrini nasıl yerine getireceği konusunda İbn Abbas'a muhalefet ederek bir koyun kesmesini vâcip görmüştür. Halbu ki İbn Abbas bir dişi deve kurban etmesini vâcip görüyordu. Bundan sonra İbn Abbas kendi görüşünden vazgeçerek Mesrûk'un görüşüne uymuştur. ${ }^{111}$ Sahâbe kavli kendilerinden sonrakiler için hüccet olsaydı Mesrûk'un İbn Abbas'a muhalefet etmemesi, İbn Abbas'in da kendi görüşünü bırakıp Mesrûk'un görüşüne uymaması gerekirdi. ${ }^{112}$

Kerhî, sahâbenin insanları kendilerini taklit etmeye ve görüşlerine uymaya davet etmediğini ileri sürerek şöyle demiştir: "Şayet sahâbî sözü hüccet olsaydı Hz. Peygamber gibi insanları kendi görüşlerine davet ederlerdi." 113 Meselâ Zeyd b. Sabit (ö. 45/665 [?]), dede hakkında verdiği bir hüküm konusunda; "Benim görüşüm müslümanlar üzerine vâcip değildir"114 demiştir. Bu sahâbîler kendilerini taklit etmelerini insanlara vâcip görmediklerine göre bizim onları taklit etmemiz nasıl vâcip olur?"115

Bu deliller, sahâbe kavliyle amel etmenin vâcip olmadı̆̆ı konusunda hüccet teşkil etmekle birlikte caiz olmayacağı konusunda hüccet teşkil etmezler. Bu konuda mâkul olan, ister Peygamber'den işiterek söylemiş olma ihtimali olsun ister re'yden sâdır olarak söylemiş olsunlar akıl ve re'y ile kavranamay-

108 Debûsî, Takvîmü'l-edille, s. 257; Semerkandî, Mîzânü'l-usûl, c. 2, s. 699; Ayrıca bk. İbnü'lKayyım, I'lâmü'-muvakkı̂̂n an Rabbi'l-âlemîn, c. 1, s. 84.

109 Debûsî, Takvîmü'l-edille, s. 257; Semerkandî, Mîzânü'l-usîul, c. 2, s. 699.

110 Semerkandî, Mîzânü'l-usûl, c. 2, s. 700.

111 Debûsî, Takvîmü'l-edille, s. 257; Semerkandî, Mîzânü'l-usûl, c. 2, s. 700.

112 Debûsî, Takvîmü'l-edille, s. 257; Semerkandî, Mîzânü'l-usîul, c. 2, s. 700.

113 Debûsî, Takvîmü'l-edille, s. 257.

114 Cessâs, el-Fusûl fì'l-usûl, c. 3, s. 364.

115 Cessâs, el-Fusûl fî'l-usûl, c. 3, s. 364. 
acak konular dışındaki sahâbe kavliyle amel etmenin vâcip değil, caiz olduğunu söylememizdir. Tıpkı diğer müçtehidlerin içtihatlarıyla amel edilmesi caiz olduğu gibi. Ebû Hanîfe ile arkadaşları da bu görüştedirler.

\subsubsection{Sahâbenin İhtilafı}

Hanefî usûlcüler sahâbenin aralarında ihtilafa düşmeleri halinde onlardan herhangi birinin kavliyle amelin vâcip olup olmadığı konusunda üç ayrı görüş belirtmişlerdir.

\subsubsection{Taklîdi Vâcip Görenler}

Çoğunluğu teşkil eden Hanefî usûlcüler sahâbenin ihtilafa düştüklerinde bunun da bir icmâ olduğunu söyleyip bunların dışında bir görüş belirtmenin caiz olmadığını söylemişlerdir. Bu görüşün ilk temsilcisi Ebû Saîd elBerdaî'dir. Ona göre iki sahâbî görüşünün tearuz etmesi halinde onlardan biri için tercih sebebi ortaya çıktığında bu görüşü almak vâcip olur. Aynı şekilde bizden birinin görüşüyle onlardan birinin re'yi arasında tearuz meydana geldiği zaman da sahâbî görüşünün daha kuvvetli olması sebebiyle onun re'yini bizim re'yimize tercih etmek vâciptir. ${ }^{116}$ İlk dönem Hanefî usûlcülerinden Cessâs da bu görüşü benimsemiştir. Cessâs'a göre Hz. Peygamber'in "Ashâbım yıldılar gibidir, hangisine uyarsanı hidayete ermiş olursunuz"117 hadisi ${ }^{118}$ sahâbeden bir kişiye uymanın caiz ve ona uymanın hidayet olduğuna delil teşkil eder. Bir tek sahâbî sözünün hidayet olduğuna hükmedilmiş olunca onu terk edip başkasının görüşüne uyulması caiz olmaz. ${ }^{119}$ Cessâs'ın bu yorumuna bakıldığında sahâbe arasında ihtilaf olduğu zaman onlardan birini taklit etmeyi vâcip gördüğü anlaşılmaktadır. Debûsî, Pezdevî ve Serahsî de bu görüşü benimseyerek sahâbenin aralarında ihtilaf ettikleri hususlarda onların görüşlerinin dışına çıkılamayacağını belirtmişlerdir. Onlara göre sahâbîler aralarında bir konuda ihtilaf ettiklerinde hak onların görüşleri içerisinde olup onların görüşlerinin dişına çıkmaz. Bu sebeple iki sahâbî görüşü tearuz ettiğinde onlardan birinin diğerine tercih yönü ortaya çıtığı zaman bu görüşü tercih etmek vâcip olur. Tercih yapmak imkânsız olursa doğrunun sadece bunlardan birisi olması itibariyle müçtehid bunlardan hangisini dilerse onun-

116 Cessâs, Fusûl, c. 3, s. 361; Debûsî, Takvîmü'l-edille, s. 256; Serahsî, el-Usûl, c. 2, s. 105, 108; Pezdevî, Usûlü'l-Pezdevî, c. 3, s. 217, 222-224.

117 İbn Hazm, İhkâm, c. 5, s. 680; Elbânî, Silsiletü'l-ehâdîsi'd-daîfe, c. 1, s. 78-79.

118 Yukarıda ifade edildiği üzere bu hadis sahih değildir.

119 Cessâs, Fusûl, c. 3, s. 363. 
la amel etmesi vâcip olur. Aynı şekilde bizden birinin re' yi ile onlardan birinin re'yi arasında tearuz meydana geldiği zaman, onların re'yleri daha kuvvetli olduğundan bizim re' yimize tercih edilmeleri vâciptir. ${ }^{120}$

Daha sonraki Hanefî usûlcülerinin çoğunluğuna göre de bir sahâbînin bir mesele hakkındaki görüşünü başka bir sahâbînin reddettiği nakledilirse bu, re'y ile hüküm konusunda sahâbe ihtilafı sayılır. Bu da aralarında tercih yapmayı gerektirir. Şayet tercih yapma imkânsız olursa müçtehid bu iki kavilden hangisini dilerse onunla amel eder. Sahâbîden başkasının o ikisine muhalif olan üçüncü bir görüş beyan etmesi caiz olmaz. Çünkü hak onların görüşlerinin dışına çıkmaz. Dolayısıyla iki kavil üzerindeki ihtilaf, onlar tarafından üçüncü görüşün butlanı hakkında icmâ' olduğundan bu iki sahâbî üçüncü görüşün reddi konusunda icmâ‘ etmiş sayılır. Sonra delil olmadıkça ikinci görüşle amel edilmesi caiz olmaz. ${ }^{121}$

\subsubsection{Taklîdi Caiz Görenler}

Bazıları tercih sebebi ortaya çıktığı zaman bunlardan birini almanın vâcip değil, caiz olduğunu söylemişlerdir. İmam Mâturîdî bu görüştedir. Ona göre başka sahâbî kendisine muhalefet ettiği zaman birini taklit etmek vâcip değildir. Fakat delile binaen birinin kavlini diğerine tercih etmek gerekir. Semerkandî de bu görüşü benimsemiştir. ${ }^{122}$ Mâturîdî ile Semerkandî’nin bu ifadelerinden ihtilaf halinde sahâbîyi taklidi vâcip değil caiz gördükleri anlaşılmaktadır. İbn Emîrü'l-Hâc da bu görüşü benimsemiştir. ${ }^{123}$

\subsubsection{Taklidi Caiz Görmeyenler}

Molla Hüsrev'e (ö. 885/1480) göre aralarında ihtilaf ettikleri hususlarda sahâbî kavli başkası için hüccet teşkil etmediğinden ona muhalefet edilmesi icmâ' ile caizdir. ${ }^{124}$ Buradaki icmâ' iddiasını anlamak zor görünüyor. Çünkü çoğunluk ihtilaf halinde delile göre ikisinden birini tercih etmenin vâcip olduğunu söylemektedir. Leknevî’ye göre bu konudaki tartışma umûmü'l-belvâ

120 Debûsî, Takvîmü'l-edille, s. 259; Pezdevî, Usûlü'l-Pezdevî, c. 3, s. 224; Serahsî, el-Usûl, c. 2, s. 108.

121 Debûsî, Takvîmü'l-edille, 259; Abdülaziz el-Buhârî, Keş̧ü'l-esrâr, c. 3, s. 223, 225; Signâkî, el-Kâfí fì Şerhi'l-Pezdevî, c. 4, s. 1591; İbn Melek, Şerhu Menâri'l-envâr, s. 253; Molla Fenârî, Fusûlü'l-bedâi', c. 2, s. 438.

122 Semerkandî, Mîzânü'l-usûl, c. 2, s. 698.

123 İbn Emîru Hâc, et-Takrîr ve't-tahbîr, c. 2, s. 415.

124 Molla Hüsrev, Mir'âtü'l-usûl, 313. 
olmayan konulardaki sahâbî sözü hakkındadır. Umûmü'l-belvâ olan konularda sahâbî sözü hükmünü bilmeye ihtiyaç duyanların ameline muhalif olursa ittifakla amel edilmesi vâcip değildir. Çünkü bu Sünnet kapsamına girmez. Dolayısıyla şüpheyi kâbil olan ve sahâbe arasında hakkında ihtilaf bulunan söz kabul edilmez. Bilakis derinlemesine düşünüp kıyasa uygun olan sözün alınması gerekir. ${ }^{125}$ Sadrüşşerîa (ö. 747/1347) ve İbn Nüceym'e göre de aralarında ihtilaf edildiği sabit olan hususlarda icmâ'en sahâbeyi taklit etmek gerekmez. ${ }^{126}$ İbn Melek de aralarında ihtilaf olan konularda sahâbî kavliyle amelin caiz olmayacağını söyleyenlerdendir. ${ }^{127}$

\subsubsection{4. İttifak Ettikleri de İhtilaf Ettikleri de Bilinmeyen Sahâbî Sözleri}

Bunun yanında itifak ettikleri de ihtilaf ettikleri de bilinmeyen sahâbî kavli konusunda Hanefîler üç ayrı görüş beyan etmişlerdir.

a. Bazıları onları taklit caiz değildir, demiştir. Çünkü onların re'y ile fetva verdikleri zahir olmuştur. Hatadan masum olmadıkları için diğer müçtehidler gibi onların da içtihadlarında hata ihtimali sabittir. Hata etme ihtimalleri olunca başka bir müçtehidin onları taklit etmesi caiz değildir. ${ }^{128}$

b. Bazılarına göre ise kıyasla bilinemeyecek konularda taklit edilmeleri vâciptir. Çünkü bu sözün Peygamber'den işitme veya yalan olmasından başka izahı yoktur. İkinci ihtimal sözkonusu edilemez. Kıyasla idrak edilebilecek hususlarda ise taklit edilmeleri gerekmez. Çünkü onların rey ile görüş beyan ettikleri meşhurdur. Müçtehid hata da eder isabet de eder. ${ }^{129} \mathrm{Bu}$ iki görüş Kerhî ile aynı çizgide olanların görüşünü çağrıştırmaktadır.

c. Bazıları ister sözü kıyasla kavranabilecek hususlarda isterse kıyasla kavranamayacak hususlarda olsun mutlak olarak taklit edilmeleri vâciptir. Çünkü onların sözleri Peygamber'den işitmeye dayanıorsa onunla amel edilir. Re'ye dayanıyorsa hükümleri beyan etme konusunda Hz. Peygamber'in takip etiği yöntemi müşahede etme, hadisleri ezberleme ve manalarını zaptetme konusundaki başkalarında olmayan aşırı titizlikleri sebebiyle onların re'yi başkalarının re'yinden daha kuvvetlidir. Bu hususiyetleri sebebiyle

Leknevî, Fevâtihu'r-rahamût, c. 2, s. 232.

126 Sadruşşerîa, Tenkîhu'l-usûl, s. 36-37; İbn Nüceym, Fethu'l-gaffâr, s. 348.

127 İbn Melek, Şerhü Menâri'l-envâr, s. 253.

128 Molla Hüsrev, Mir'âtü'l-usûl, s. 313.

129 Molla Hüsrev, Mir'âtü'l-usûl, s. 313. 
onların re'yleri başkalarının re'yine tercih edilir. Bu sebeple de taklit edilmeleri vâcip olur. ${ }^{130} \mathrm{Bu}$ görüşü ise Ebû Saîd el-Berdaî ve taraftarlarının benimsediği anlaşılıyor.

\section{Sonuç}

Hanefî mezhebi imamlarına nispet edilen rivayetlere ve onların fıkhî çözümlemelerine bakıldığında onların sahâbenin üzerinde icmâ ettiği ve re'y ile kavranamayacak konularda arkadaşlarından hiçbirinin muhalefet etmediği sahâbe kavliyle mutlaka amel ettiklerini bu iki konu dişındaki sahâbe kavliyle bazen amel edip bazen de terk ederek kendi içtihatlarıyla amel ettiklerini görüyoruz. Mezheb imamlarının bu uygulamalarından hareketle re'y ile kavranamayacak konulardaki sahâbe kavlini Peygamber'den duymuş olmalarına hamlederek onunla ameli vâcip, kıyas yoluyla ve re' yle bilinebilecek konulardaki sahâbe kavliyle ameli ise vacip değil, caiz gördükleri anlaşılmaktadır. Ebû Hanîfe' ye isnad edilen rivayetler de bunu doğrular niteliktedir. Bununla birlikte Ebû Saîd el-Berdaî ve ondan sonraki Hanefî usûlcülerin kahir ekseriyeti sahâbeden bir söz nakledilmişse hiçbir şekilde onların sözlerinin dışına çıkmanın caiz olmadığı, hatta iki farklı sahâbî kavli söz konusu olduğunda bunun üçüncü bir görüş beyan edilemeyeceğine dair sahâbe icmâ‘'1 olduğu görüşünü benimsemişlerdir. Buna karşılık Ebü'l-Hasen el-Kerhî mekâdîr-i şer'iyye gibi re'y ile kavranamayacak konular dışında sahâbî kavliyle amel etmenin caiz olmadığını söylemiştir.

$\operatorname{Re}^{\prime} y$ ile bilinebilecek konulardaki sahâbe kavli ile ilgili bu görüşlerin her ikisinin de uç noktaları temsil ettiğini söylememiz gerekir. Sahâbî bir insandır, hatadan ve yanlıştan masum değildir. Dolayısıyla görüşlerinde isabet etmiş olmaları ihtimali kadar hata etmiş olmaları ihtimali de vardır. Böyle bir ihtimal söz konusu olunca sözlerinin mutlak hüccet olacağını söylemek imkânsızdır. Onlar her ne kadar nassların nüzul ve vüruduna şahit olsalar da hakkında nass olmayan birçok konuda kendi içtihatlarıyla görüşler ortaya koymuşlardır. Bu görüşlerinde hata etmeleri de isabet etmeleri de mümkündür. Nitekim onların verdikleri hükümlerde hatalı olduklarını anladıkları zaman o konuda Peygamber'den nakledilen rivayete veya arkadaşının içtihadına döndüğünü gösteren birçok örnek vardır. Bu da onların ellerinde nass bulunmadığı zaman re'yleriyle görüş beyan ettiklerini göstermektedir. Bu sebeple Ebû Saîd el-Berdaî ve taraftarlarının sahâbeyi Peygamber'den sonra di- 
nin kaynağıymış gibi gören ve sahâbî kavlini mutlak hüccet sayan yaklaşımı isabetli bir yaklaşım olarak gözükmemektedir.

Buna karşılık re'y ile bilinemeyecek konular dışında onların sözlerine uymanın caiz olmadığını söyleyen Kerhı̂’nin yaklaşımı da aynı şekilde isabetli bir yaklaşım olarak gözükmemektedir. Ebû Hanîfe'nin de kabul ettiği üzere bir âlim kendisinden daha âlim bir kimsenin içtihadına uyabilir. Bu bakış açısından hareketle sahâbî kavli konusunda makul olan, hakkında nass bulunmayan konularda daha sağlam bir delil bulunamadığı zaman Kur'an ve Sünnet'in genel esaslarıyla akla aykırı olmayan sahâbî kavliyle amel etmenin vâcip değil, caiz olduğunu söylemektir. Mezheb imamlarına isnat edilen rivayetlerden ve uygulamalarından, sahâbe icmâ'1 ve onlardan hiç birinin muhalefet etmediği kıyasa aykırı sözleri dışında kalan bir tek sahâbî kavli konusunda onların benimsedikleri görüşün de bu olduğu anlaşılmaktadır. Aynı şekilde masum olmadıkları için kıyasa aykırı olan sahâbî kavilleri konusunda da ihtiyatın elden bırakılmaması, Kur'an ve Sünnet'in genel ilkelerine ve akla aykırı olmayan sözlerinin alınması daha makul bir yaklaşım olarak görülmektedir. Zira bu konularda da sahâbînin uzak bir tevilde bulunarak fetva vermiş olması ihtimali gözden uzak tutulmamalıdır.

\section{Kaynakça}

Abdülaziz el-Buhârî, Alâuddîn Abdülaziz b. Ahmed, Keşfü'l-esrâr an usûli Fahri'l-İslâm el-Pezdevî, Kâhire, Dâru'l-kitâbi'l-İslâmî, ts.

Abdürrezzâk, Ebû Bekir Abdürrezzâk b. Hemmâm es-San’ânî, el-Musannef, tahk.: Habîbü'r-rahman elA’zamî, Beyrut. yy. 1987.

Alâî, Salahuddin Ebû Saîd Halil b. Abdillah ed-Dımeşkî, İcmâlü'l-isâbe fî akvâli's-sahâbe. tahk.: Muhammed Süleyman el-Aşkar, Kuveyt, 1407.

Apaydın, Hacı Yunus. "Sahâbî Sözünün Hukukî Değeri”, Erciyes Üniversitesi Sosyal Bilimler Enstitüsü Dergisi, say1: 4, 1990. (323-353).

Arslan, Ali, Hadiste Metin Tenkidi Prensibi Olarak Tarihe-Vakıaya Aykırılık, Kastamonu, 2013.

"Râvinin Rivâyetine Muhâlif Amel Etmesi Konusunun Hadis Usûlü ve Hanefî Fıkıh Usûlü Eserlerinde Ele Alınışı”, Akademik Sosyal Araştırmalar Dergisi, sayı: 5, 2017. (88-100).

Beyhakî, Ahmed b. El-Hüseyin b. Ali b. Musa, el-Medhal ilâ Süneni'l-kübrâ, tahk.: Muhammed Zıyâu’r-rahmân el-A'zamî, Kuveyt: Dârul-hulefâu li’l-kitâbi’l-İslâmî, ts.

Cessâs, Ebû Bekir Ahmed b. Ali er-Râzî, el-Fusûl fì'l-usûl, tahk.: Acîl Câsim en-Neşmî, Kuveyt, el-Mektebetü'l-irşâd, 1994.

Çolak, Abdullah, İslâm Hukuk Tarihi ve İslâm Hukukunun Delilleri, Malatya, 2014.

Debûsî, Ebû Zeyd Ubeydullah b. Ömer, Takvîmü'l-edille fî̀ usûli'l-fikh, tahk.: Halil Muhyiddin el-Müysü, Beyrut, Dâru'l-kütübi'l-ilmiyye, 2007. 
Debûsî, Te'sîsü'n-nazar, tahk.: Mustafa Muhammed el-Kabânî ed-Dımeşkî, Beyrut, el-Mektebetü’l-külliyeti'l-ezheriyye, ts.

Ebû Ya'lâ, Muhammed b. Huseyn b. Muhammed el-Ferrâ, el-Udde fì usûli'l-fikh, tahk.: Ahmed b. Ali b. Seyyid el-Mübarekî, Riyad, 1990.

Ebû Zehra, Muhammed, Usûlü'l-fikh, Dâru'l-fikr, 1958.

Elbânî, Muhammed Nâsıruddin, Silsiletü'l-ehâdîsi'd-daîfe, Beyrut, el-Mektebetü'l-İslâmî, 1985.

Gazzâlî, Ebû Hâmid Muhammed b. Muhammed, el-Mustasâ min ilmi'l-usûl, Beyrut, el-Mektebetü'asriyye, 2008.

Günay, Musa, “İmam Ebû Hanîfe’nin Sahâbî Kavli ile İlgili Görüş ve Uygulamaları”, Harran Üniversitesi Illahiyat Fakültesi Dergisi, Yıl: 18, sayı: 29, 2013, (126-141).

Hâkim, Ebû Abdillah el-Hâkim Muhammed b. Abdillah en-Nisâbûrî. el-Müsredrek ale's-Sahîhayn, tahk.: Mustafa Abdulkâdir Atâ, Beyrut, Dâru'l-kütübi'l-ilmiyye, 1990.

Hallâf, Abdülvehhâb, Islâm Hukuk Felsefesi, çev.: Hüseyin Atay, Ankara: 1973.

Herevî, Ebû İsmail Abdullah b. Muhammed b. Ali el-Ensârî, Zemmü'l-kelâm ve ehlih, tahk.: Abdurrahman Abdülaziz eş-Şebel, el-Medinetü'l-münevvere, 1998.

Hudârî, Muhammed, İslâm Hukuku Tarihi, çev.: H. Hatipoğlu, İstanbul, Kahraman Yayınları, 1974.

İbn Abdilber, Ebû Ömer Yûsuf b. Abdillah en-Nemirî, Câmiu beyani'l-ilm ve fadlih, tahk.: Ebû Abdurrahman Fevvaz Ahmed Zümerlî, Dâru İbn Hazm, 2003. el-İntifâ' fî fedâili's-selâseti'l-eimmeti'l-fukahâi Mâlik ve'ş-Şâfî̀ ve Ebî Hanîfe. Beyrut, yy., ts.

İbn Ebi'l-Avvâm, Ebü'l-Kâsım Abdullah b. Muhammed b. Ahmed b. Hâris es-Sa dî, Fedâilü Ebî Hanîfe ve ahbâruhu ve menâkıbuh, tahk.: Latîfü'r-Rahmân el-Behrâicî el-Kâsımî, Mekketü’l-mükerreme, el-Mektebetü'l-imdâdiyye, 2010.

İbn Ebi'l-İz, Ebü'l-Hasen Sadruddîn Muhammed b. Alâuddîn Ali b. Muhammed el-Hanefî, Şerhu'l-akîdeti't-Tahâviyye, Mektebetü'l-İslâmî, 2005.

İbn Ebî Şeybe, Ebû Bekir Abdullah b. Muhammed, el-Musannef, tahk.: Kemal Yûsuf el-Hût, Riyad, yy. 1409 ,

İbn Emîru Hâc, et-Takrîr ve't-tahbîr fì usûli'l-fikh, Beyrut, Dâru'l-kütübi'l-ilmiyye, 1996.

İbn Hacer, Ahmed b. Ali b. Hacer el-Askalânî, Fethu'l-bârî bi şerhi Sahîhi'l-Buhârî, tahk.: Muhammed Fuad Abdülbâkî ve Muhibbüddin el-Hatîb, Kâhire, Dâru'l-beyân li’t-türâs, 1986.

İbn Hacer, el-İsâbe fì temyîzi's-sahâbe, Beyrut, Dâru'l-kütübi'l-ilmiyye, ts.

İbn Hazm, Ebû Muhammed Ali b. Ahmed b. Saîd, el-İhkâm fî usûli'l-ahkûm, tahk.: Mahmud Hâmid Osman, Kâhire, Dâru'l-hadîs, 2005.

İbnü'l-Hümâm, Kemalüddin Muhammed b. Abdülvahid es-Sıvâsî, et-Tahrîr, Beyrut, Dâru'l-kütübi'l-ilmiyye, ts.

İbn Hüsrev, Ebû Abdullah el-Hüseyin b. Muhammed b. Hüsrev el-Belhî el-Hanefî, Müsnedü'l-İmam el-A ‘zam Ebî Hanîfe en-Nu'mân b. Sâbit, tahk.: Latîfü'r-Rahman el-Behrâicî el-Kâsımî, Mekketü'l-Mükerreme: el-Mektebetü'l-imdâdiyye, 2010

İbnü'l-Kayyım, Şemsüddîn Ebû Abdillah Muhammed b. Ebî Bekir el-Cevziyye, I'lâmü'l-muvakkl'în an rabbi'l-âlemin, tahk.: Muhyiddin Abdülhamid, Beyrut, Dâru'l-fikr, 1977.

İbn Kutluboğa, Ebü'l-Fidâ Zeynüddin Kâsım b. Kutluboğa el-Hanefî, Hulâsatü'l-efkâr şerhu Muhtasari’l-Menâr, tahk.: Hâfız Senâullah ez-Zâhidî, Dâru ibn Hazm, 2003.

İbn Melek, İbn Firişte İzzeddin Abdüllatif b. Abdilaziz, Şerhu Menâri'l-envâr fî usûli'l-fikh, İstanbul, Salah Bilici Kitabevi, ts. 
İbn Nüceym, Zeynüddin Zeyn b. İbrâhim b. Muhammed Misri el-Hanefî, Fethü'l-gaffâr bi-şerhi'l-Menâr, Beyrut, Dâru'l-kütübi'l-ilmiyye, 2001.

İbrahim, Musa İbrahim, el-Medhal ila usûli'l-fikh ve târihi't-teşrî'il-İslâmî, Amman, 1989.

İbnü's-Saâtî, Ahmed b. Ali b. Tağleb b. Ebi’z-Ziya, Nihâyetü'l-vüsûl ilâ ilmi'l-usûl, tahk.: Hasan İsbir, Beyrut, Dâru'l-kütübi'l-ilmiyye, 2004.

Leknevî, Abdülalî Muhammed b. Nizâmüddin Muhammed es-Sehâlevî, Fevâtihu'r-rahamût bi şerhi Müsellemi's-sübût, neş.: Abdullah Mahmûd Muhammed Ömer, Beyrut, Dâru'l-kütübi'l-ilmiyye, 2002.

Leknevî, Ebü'l-Hasenât Abdülhayy b. Muhammed, en-Nâfiu'l-kebîr şerhu'l-Câmii’s-să̆îr, Beyrut, yy. 1986.

Molla Fenârî, Şemsüddin Muhammed b. Hamza b. Muhammed, Fusûlü'l-bedâî‘ fì usûli'ş-şerâi ', tahk.: Muhammed Hasan Muhammed Hasan İsmâil, Beyrut, Dâru'l-kütübi'l-ilmiyye, 2006.

Molla Hüsrev, Muhammed b. Ferâmûz, Mir 'âtü’l-usûl Şerhu Mikâti’l-vüsûl, tahk.: İlyas Kaplan et-Türkî, Beyrut, Dâru Sâdır, 2011.

Nas, Taha, "İmam Şâfî̀’nin Sahâbe Kavline Bakışı", Artuklu Akademi Dergisi (Journal of Artuklu Academia), 2014/1 (1), s. 183-208.

Nesefî, Ebü'l-Berekat Hafızüddin Abdullah b. Ahmed b. Mahmûd Nesefî, Menâru'l-envâr, (İbn Melek'in şerhi içerisinde), İstanbul, Salah Bilici Kitabevi. ts.

Özdemir, Recep, “İmam Malik'in Metodolojisinde Sahâbî Kavlinin Delil Değeri”, Türk-İslâm Medeniyeti akademik Araştırmalar Dergisi, Y11. 11, say1: 22, Konya, 2016, (203-225).

Pezdevî, Ebü'l-Hasan Ali b. Muhammed, Usûlü'l-Pezdevî (Abdülaziz el-Buhârî'nin Keşfü'l-esrâr an Usûli fahri'l-İslâm el-Pezdevî adlı şerhi içinde), Kahire, Dâru'l-Kitâbi'l-İslâmiyye, ts.

Sadruşşerî‘a, Ubeydullah b. Mes ‘ûd b. Mahmud el-Mahbûbî el-Buhârî el-Hanefî, Tenkîhu’l-usûl fì halli gavâmi't-'tenkih (Taftazânî'nin Şerhu't-telvîh ale't-Tavzîh li metni't-Tenkîh fì usûli'l-fikh adlı eseri içinde), Mısır, 1996.

Saîd b. Mansur, Sünen-i Saîd b. Mansur, tahk.: Habîbürrahman el-A‘zamî, Beyrut, Dâru'l-fikr, 1985.

Sem ‘ânî, Ebü'l-Muzaffer Mansur b. Muhammed b. Abdilcebbâr, Kavâtiü‘l-edille fî’l-usûl, tahk.: Muhammed Hasan Muhammed Hasan İsmâîl eş-Şâfî̂, Beyrut: Dâru'l-kütübi’l-ilmiyye. 1997.

Semerkandî, Ebü'l-Leys Nasr b. Muhammed b. Ahmed, Uyûnü'l-mesâil, tahk.: Selâhaddîn en-Nâhî, Bă̆dat, yy. 1966.

Semerkandî, Alâuddin Şemsünnazar Ebû Bekir Muhammed b. Ahmed, Mîzânü'l-usûl fî̀ netâici'l-ukûl, tahk.: Abdülmelik Abdurrahman es-Sa‘dî, Mekketü’-1-mükerreme: el-Vüzâratü’l-evkâf, 1987.

Serahsî, Muhammed b. Ahmed b. Ebî Sehl, el-Usûl, İstanbul, Kahraman Yayınları. 1984.

Serahsî, el-Mebsût, Beyrut, Dâru'l-fikr, 1993.

Signâkî, el-Hüseyin b. Ali b. Haccâc b. Ali Hüsâmüddin, el-Kâfî fî Şerhi’l-Pezdevî, tahk.: Fahruddin Seyyid Muhammed Gânit, Kâhire, yy. 2001.

Şâfiî, Muhammed b. İdris, er-Risâle, tahk.: Ahmed Muhammed Şakir, Beyrut, ts.

Şîrâzî, Ebû İshak İbrahim b. Ali b. Yûsuf, et-Tebsıra fî usûli'l-fikh, tahk.: Muhammed Hasen Muhammed Hasen İsmail, Beyrut, Dâru'l-kütübi'l-ilmiyye, 2003.

Taberânî, Süleyman b. Ahmed b. Eyyub, el-Mu'cemü’l-evsât, tahk.: Tarık b. Ivazullah b. Muhammed-Abdülmuhsin b. İbrahim el-Huseynî, Kâhire, yy. ts.

el-Mu'cemü’s-sagîr, tahk.: Muhammed Şekûr Mahmud el-Hâc, Beyrut, Dâru'l-kütübi'l-ilmiyye, 1985 . 
Taftazânî, Sa‘düddin Mes'ûd b. Ömer, Şerhu't-Telvîh ale’t-tavzih li metni't-Tenkîh fî usûli’l-fikh, tahk.: Zekeriyya Umeyrât, Beyrut, yy. 1996.

Uzunpostalcı, Mustafa, “İlk İki Asırda Fıkıh”, Selçuk Üniversitesi İlahiyat Fakültesi Dergisi, sayı: 2, Konya, 1986.

Yahya b. Maîn, Ebû Zekeriya, Târihu Yahya b. Maîn, tahk.: Ahmed Muhammed Nur Seyf, Mekketü'l-Mükerreme, el-Mektebetü'l-imdâdiyye, 1979.

Yaman, Ahmed ve Çalış, Halit, İslâm Hukukuna Giriş, İstanbul, İFAV yayınları, 2012.

Zeylaî, Cemâlüddîn Ebû Muhammed Abdullah b. Yûsuf, Nasbu'r-râye li ehâdîsi'l-Hidâye, Kâhire, Dâru'l-hadîs, ts. 